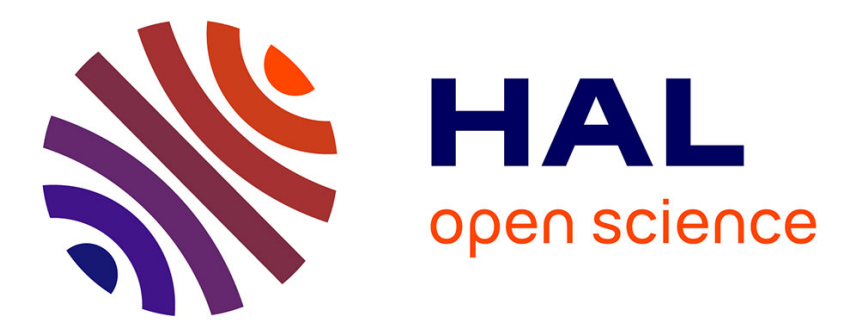

\title{
Oligo-Miocene thinning of the Beni Bousera peridotites and their Variscan crustal host rocks, Internal Rif, Morocco $\dagger$
}

Frédéric Gueydan, Pavel Pitra, Abdelkhaleq Afiri, Marc Poujol, Abderrahim Essaifi, Jean-Louis Paquette

\section{To cite this version:}

Frédéric Gueydan, Pavel Pitra, Abdelkhaleq Afiri, Marc Poujol, Abderrahim Essaifi, et al.. OligoMiocene thinning of the Beni Bousera peridotites and their Variscan crustal host rocks, Internal Rif, Morocco†. Tectonics, 2015, 34 (6), pp.1244-1268. 10.1002/2014TC003769 . insu-01152517

\section{HAL Id: insu-01152517 https://hal-insu.archives-ouvertes.fr/insu-01152517}

Submitted on 3 Jul 2015

HAL is a multi-disciplinary open access archive for the deposit and dissemination of scientific research documents, whether they are published or not. The documents may come from teaching and research institutions in France or abroad, or from public or private research centers.
L'archive ouverte pluridisciplinaire HAL, est destinée au dépôt et à la diffusion de documents scientifiques de niveau recherche, publiés ou non, émanant des établissements d'enseignement et de recherche français ou étrangers, des laboratoires publics ou privés. 


\section{Tectonics}

\section{RESEARCH ARTICLE}

10.1002/2014TC003769

Key Points:

- Deciphering Hercynian and Alpine deformation and metamorphism

- Precise P-T constraints for crustal rocks overlying the Beni Bousera peridotites

- In situ dating of regional foliation and

remnant of a previous deformation stage

Correspondence to:

F. Gueydan,

frederic.gueydan@um2.fr

\section{Citation:}

Gueydan, F., P. Pitra, A. Afiri, M. Poujol, A. Essaifi, and J.-L. Paquette (2015), Oligo-Miocene thinning of the Beni Bousera peridotites and their Variscan crustal host rocks, Internal Rif, Morocco, Tectonics, 34, doi:10.1002/2014TC003769.

Received 30 OCT 2014

Accepted 1 MAY 2015

Accepted article online 6 MAY 2015

○2015. American Geophysical Union All Rights Reserved.

\section{Oligo-Miocene thinning of the Beni Bousera peridotites and their Variscan crustal host rocks, Internal Rif, Morocco}

\author{
Frédéric Gueydan ${ }^{1}$, Pavel Pitra ${ }^{2}$, Abdelkhaleq Afiri ${ }^{3}$, Marc Poujol ${ }^{2}$, Abderrahim Essaifi ${ }^{4}$, \\ and Jean-Louis Paquette ${ }^{5}$
}

${ }^{1}$ Géosciences Montpellier, UMR CNRS 5243, Université Montpellier, Montpellier, France, ${ }^{2}$ Géosciences Rennes, UMR CNRS 6118, Université Rennes 1, Rennes, France, ${ }^{3}$ Facultés des Sciences et Technique B.P 509 Boutalamine, Errachidia, Morocco, ${ }^{4}$ Laboratoire Dynamique de la Lithosphere et Genèse des Ressources "DLGR" (Unité Associée au CNRST, URAC 43), Faculté des Sciences Semlalia, Université Cadi Ayyad, Marrakech, Morocco, ${ }^{5}$ Laboratoire Magmas et Volcans, UMR CNRS 6524, Université Blaise Pascal, Clermont-Ferrand, France

Abstract Deciphering Variscan versus Alpine history in the Internal Rif system is a key to constrain the tectonic evolution of the Alboran domain and hence the geodynamics of the western Mediterranean system during the Cenozoic. This study focuses on the evolution of the metamorphic envelope of the Beni Bousera massif and its relation to the underlying peridotites. Combining structural geology, metamorphic petrology, and laser ablation inductively coupled plasma mass spectrometry U-Th-Pb dating of monazite, this study contributes to the understanding of the tectonic history of the western Internal Rif. The regional foliation (S2) is characterized by low pressure-high temperature (LP-HT) mineral assemblages and obliterates a former foliation (S1) developed along a Barrovian (medium pressure-medium temperature, MP-MT) metamorphic gradient. The dating of some metamorphic monazite grains from a micaschist and a migmatitic gneiss demonstrates that the crustal envelope of the peridotite recorded two distinct tectonometamorphic episodes. Data from monazite inclusions in S1 garnet suggest that the first event, D1, is older than 250-170 Ma and likely related to the Variscan collision, in agreement with the Barrovian type of the metamorphic gradient. The second event, D2, is Alpine in age (at circa $21 \mathrm{Ma}$ ) and corresponds to a strong lithosphere thinning allowing subsequent subcontinental mantle exhumation. Such a tectonic context provides an explanation for the LP-HT metamorphic gradient that is recorded in the regional foliation of the western Betic-Rif system. This extension is probably related to a subduction slab rollback in the western end of the Mediterranean realm during the Oligo-Miocene times. No evidence for a Tertiary high pressure/low temperature metamorphism has been identified in the studied area.

\section{Introduction}

Defining the relationship between deformation history and metamorphism in orogenic domains is a critical factor to understand the processes involved in mountain building. This aspect is of particular relevance when younger orogenic belts are superposed onto older orogenic domains, which leads to structural and mineralogical reworking of the original rock fabric.

The Betic-Rif orogen is a typical example of such complex relationships. This orogenic belt resulted from the closure of the westernmost part of the Tethys Ocean between Africa and the Iberian Peninsula during the Cenozoic times [Lonergan and White, 1997; Chalouan et al., 2008; Vergés and Fernàndez, 2012; Platt et al., 2013]. This process involved and reworked rocks that have been previously deformed and metamorphosed during the Variscan orogeny [Chalouan et al., 2008, and references therein]. The metamorphic rocks display the superposition of various mineral assemblages characteristic of contrasting geothermal gradients and hence tectonic settings [Michard et al., 2002, 2006]. Variscan as well as Cenozoic ages have been retrieved from the metamorphic rocks [Montel et al., 2000; Rossetti et al., 2010; Massonne, 2014]. The belt is also characterized by the occurrence of the world largest peridotite bodies enclosed in a crustal metamorphic envelope [Obata, 1980; Van der Wal and Vissers, 1993]. In the absence of a clearly established relation between the various metamorphic and tectonic events, contrasting hypotheses have been proposed for the origin of the peridotite bodies: (i) mantle core complex [Doblas and Oyarzun, 1989], (ii) extrusion of a mantle wedge during transpression along a subducting slab [Tubía et al., 2013; 


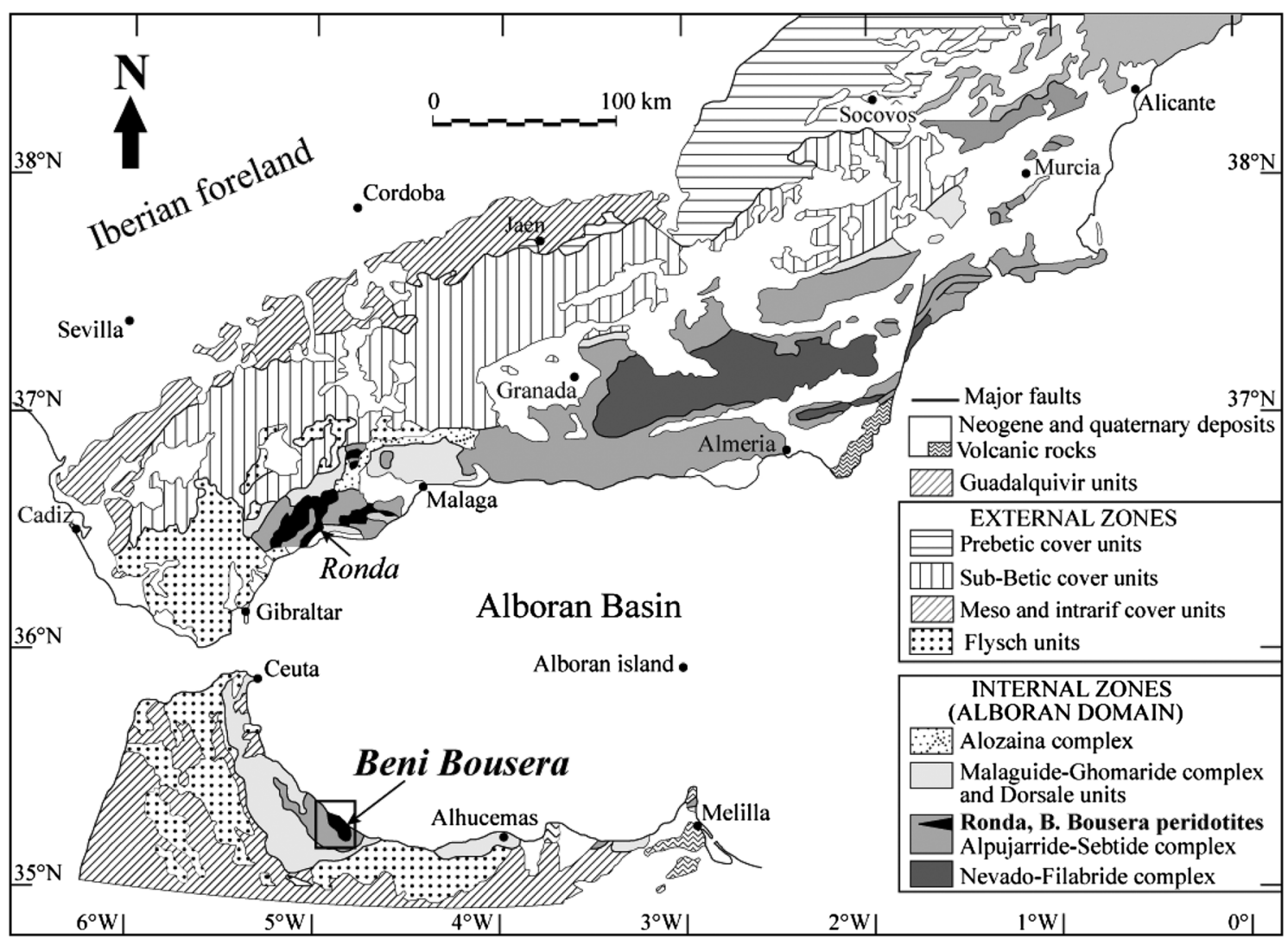

Figure 1. Geological map of the Alboran domain (Rif and Betic Cordillera), modified after Sánchez-Gómez et al. [2002]. The location of the studied area is indicated by an open black box.

Mazzoli and Martín-Algarra, 2011], (iii) successive detachment faults during extensional collapse of the Betic-Rif chain [Van der Wal and Vissers, 1993; Platt et al., 2003b], and (iv) the inversion of a thinned back-arc lithosphere during slab rollback [Garrido et al., 2011; Afiri et al., 2011; Précigout et al., 2013]. The supposed ages of peridotites exhumation also strongly vary: (i) Paleozoic [Kornprobst, 1974; Ruiz Cruz and Sanz de Galdeano, 2014], (ii) Mesozoic [Tubía et al., 2009], and (iii) Oligo-Miocene [Hidas et al., 2013; Précigout et al., 2013].

In this context, we linked a detailed structural study with the calculation of a series of P-T pseudosections and in situ laser ablation inductively coupled plasma mass spectrometry (LA-ICP-MS) monazite dating in order to reconstruct the polyorogenic P-T evolution the Internal Rif, which is one of the most poorly understood segments of the internal Alpine orogenic belt in the western Mediterranean area (i.e., Rif-Betic and Apennine-Calabrian-Maghrebian belt).

\section{Geological Setting}

The Alboran domain, spanning between the Betic Cordillera in southern Spain and the Rif orogen in northern Morocco (Figure 1), exposes a complex of nappes that are stacked and subsequently thinned during a complex Cenozoic history, as well as the exceptional exposure of large bodies of subcontinental peridotite [Dikey et al., 1979; Obata, 1980].

The internal domain of the Rif cordillera shows two nappe complexes, from the bottom to the top (Figure 1): (1) the Sebtide complex containing metasediments of Paleozoic to Triassic ages that recorded variable degrees of metamorphism from high pressure-low temperature during the Oligo-Miocene [Bouybaouène et al., 1995; Goffè et al., 1996; Agard et al., 1999], to low pressure-high temperature during the Miocene [Negro et al., 2006; El Maz and Guiraud, 2001] and which contains remnants of Variscan metamorphism [Michard et al., 1997; Bouybaouène et al., 1998; Montel et al., 2000]; and (2) the Ghomarides complex, which 
comprises Paleozoic to Tertiary sediments showing only very low grade metamorphism (see the review in Chalouan et al. [2008]). The Beni Bousera peridotite outcrops within the high-grade metamorphic crust of the Lower Sebtides (Figure 1) [Kornprobst, 1974; Saddiqi et al., 1988; Reuber et al., 1982]. It is an equivalent of the Ronda peridotite in the Betic Cordillera. Gravimetric data suggest that these peridotite bodies correspond to slices that are a few kilometers thick, are underlain by crustal material, and probably extend offshore [Tornè et al., 1992]. The occurrence of graphite pseudomorphs after diamond testifies for their very deep origin [Pearson et al., 1989; Davies et al., 1993]. Two major petrological facies crop out in the Beni Bousera peridotite: spinel Iherzolite in the core of the massif and garnet/spinel lherzolite/harzburgite in the rim of the massif, at the contact with the overlying granulite, gneiss, and micaschists of the Lower Sebtides (Filali unit).

At the scale of the Alboran domain, two "Alpine" high pressure-low temperature (HP-LT) events have been identified (review in Platt et al. [2013]): one of Eocene age, only recorded in Alpujarrides/Sebtides, and the other of Miocene age (Nevado Filabrides in Spain). In the Rif, HP-LT metamorphism is described in the Upper Sebtides units (Federico, Beni Mezala) [Chalouan and Michard, 2004, and references therein] that is overlying the Filali unit of the Lower Sebtides (crust/mantle), from which no HP-LT evidences are reported. Conversely, the Filali unit shows MP-HT conditions, with very high metamorphic grade at the crust-mantle contact [Negro et al., 2006; El Maz and Guiraud, 2001]. The contact between the Upper and Lower Sebtides is therefore most probably a thrust, coeval with the Eocene subduction system [Chalouan and Michard, 2004]. Consistently, the ensemble of the Ghomarides and the Sebtides is also interpreted as a nappe stack [Chalouan and Michard, 2004]. The same nappe stack is observed in the Spanish equivalent of the Sebtides: the Upper Alpujarrides with HP-LT metamorphism [Azañon and Goffé, 1997] and the Lower Alpujarrides with mostly high-grade (HT) rocks [Balanyá et al., 1997].

In the Lower Sebtides/Alpujarrides units, high- to ultrahigh-pressure conditions have been reported both in the Rif (Ichendirene mafic granulite) [Bouybaouène et al., 1998] and in the Betics (kinzigite in the Jubrique Units) [Ruiz Cruz and Sanz de Galdeano, 2014] with a probable Variscan age for the peak pressure.

The ages and tectonic processes involved in the exhumation and emplacement of the Ronda/Beni Bousera peridotites into the continental crust also suggest a polycyclic deformation history. The margin of the massif is strongly mylonitic with foliation and shear criteria concordant with those found in the crustal rocks above. This suggests that the garnet/spinel mylonite resulted from strain localization and that the emplacement of the peridotites resulted from lithosphere thinning and related uplift of the lithospheric mantle [Kornprobst, 1974; Reuber et al., 1982; Saddiqi et al., 1988; Michard et al., 1991; Afiri et al., 2011] followed by a late thrusting of these peridotites body onto the crust. Late Variscan to Mesozoic metamorphic ages obtained in the high-grade Paleozoic rocks [Montel et al., 2000; Massonne, 2014] together with granitoids dated at $300 \mathrm{Ma}$ [Rossetti et al., 2010; Sánchez-Navas et al., 2014] were used to suggest that the exhumation and thinning of the Beni Bousera/Ronda peridotites occurred during the late Variscan extensional collapse, followed by a Mesozoic rifting [Reuber et al., 1982; Chalouan et al., 2001; Michard et al., 2002; Chalouan and Michard, 2004; Ruiz Cruz and Sanz de Galdeano, 2014]. However, several first-order geological observations question this hypothesis, as recently discussed in Afiri et al. [2011]. First, Alpine ages are reported from the peridotites [Blichert-Toft et al., 1999; Pearson and Nowell, 2004], for the high-temperature metamorphism in the crustal rocks surrounding the peridotites [Michard et al., 1983, 1991; Chalouan et al., 2008; Saddiqi, 1995; Montel et al., 2000; Platt et al., 2003a; Negro et al., 2006; Michard et al., 2006; Massonne, 2014], and from granitoid dykes [Rossetti et al., 2010]. Monazite and zircon dating show the polycyclic (Variscan and Alpine) character of the metamorphism of the granulite overlying the Beni Bousera peridotite [Sánchez-Rodriguez and Gebauer, 2000; Montel et al., 2000]. Second, an important thinning of the crustal section overlying the peridotites, contemporaneous with the HT metamorphism, has been documented in Spain and dated at 30-25 Ma [Balanyá et al., 1993, 1997; Azañón et al., 1998, 1997; Argles et al., 1999]. Thus, the exhumation of the Beni Bousera peridotites is most probably related to a combination of Variscan, Jurassic, and Cenozoic events.

Through a new structural study together with structurally constrained P-T and age estimates, our goal is to decipher the metamorphic and deformational pattern recorded within the Beni Bousera peridotites and their crustal envelope, in order to identify the Variscan and Cenozoic contributions and to constrain the effects of the Cenozoic events on the peridotite exhumation. 


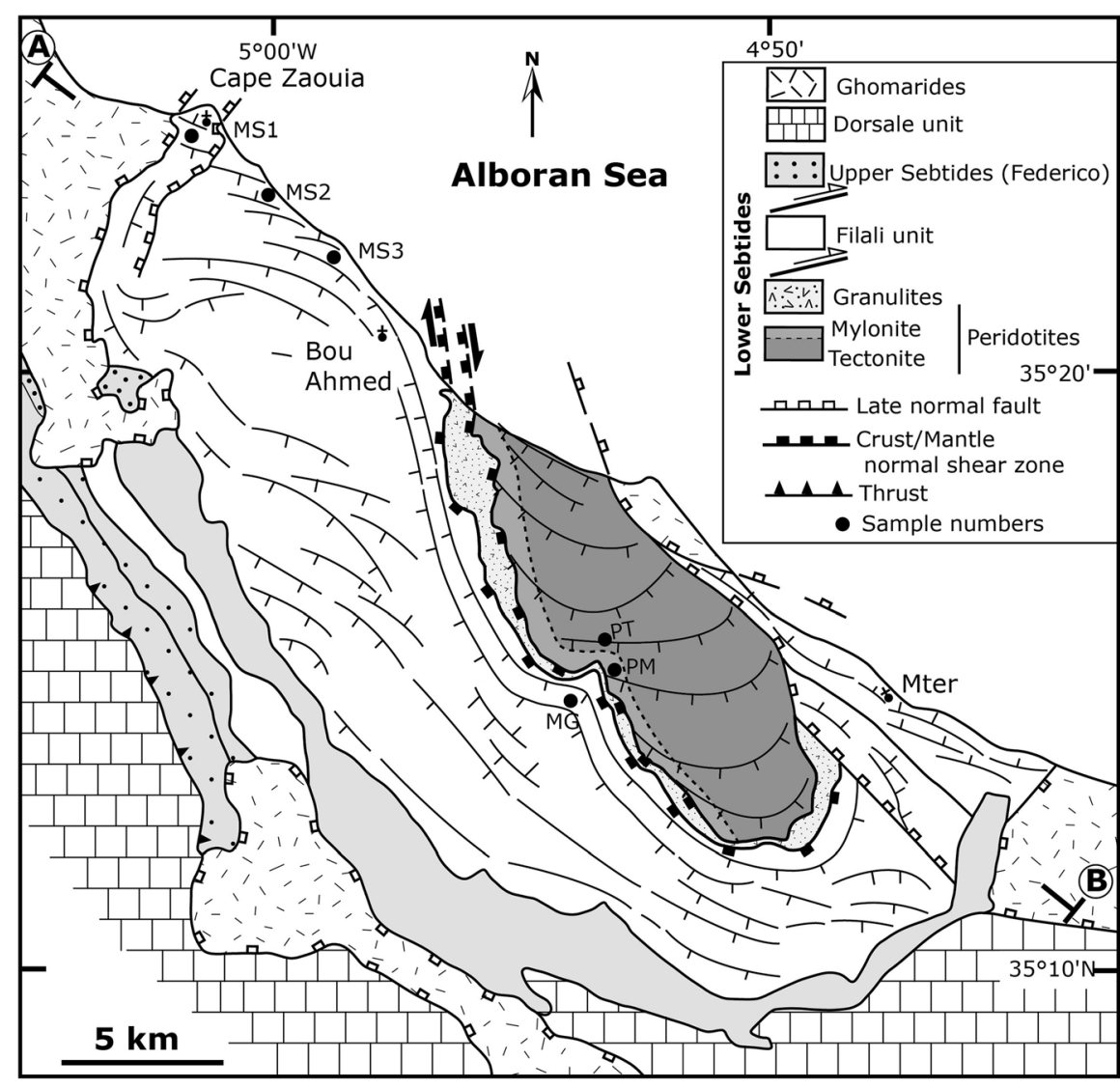

A

NW

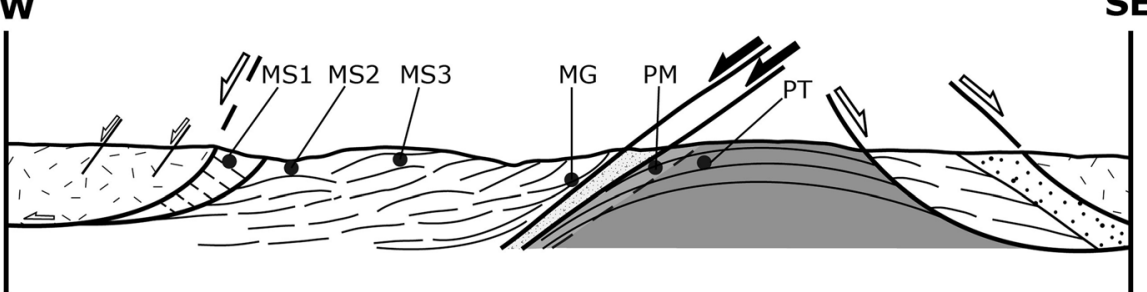

四Ghomarides

LOWER SEBTIDES

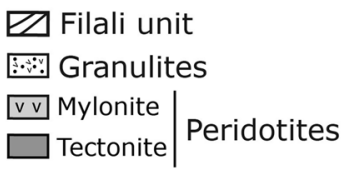

::: Upper sebtides

$5 \mathbf{~ k m}$

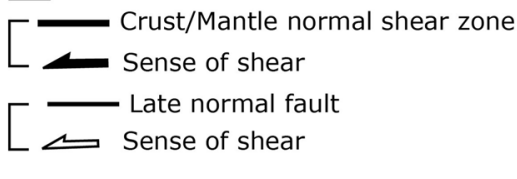

Figure 2. (A) Tectonic map of the Beni Bousera peridotites and the overlying crustal rocks (granulite and Filali units) showing the main foliation (S2) trajectories and stretching lineations. Foliation data from Reuber et al. [1982] and our own data are shown as white and black symbols, respectively. (B) NW-SE cross section showing that the crust/mantle contact is interpreted as a lithosphere-scale extensional shear zone. Position of the samples (MS1, MS2, MS3, and MG) used for petrological and geochronological studies is shown in both the map and the cross section. P-T and PM samples from peridotites were used in Afiri et al. [2011] and related P-T conditions are plotted in Figure 11.

\section{Structure}

The Beni Bousera peridotites and their crustal envelope are referred to as the Lower Sebtides. From bottom to top, they comprise the Beni Bousera peridotite, a migmatitic granulite, and a gneiss and micaschist of the Filali unit. 
The structure of the peridotite and the immediately overlying migmatitic granulite has been described in detail by Afiri et al. [2011] and also in Kornprobst [1974], Reuber et al. [1982], and Saddiqi [1995]. In summary, the core of the Beni Bousera peridotite massif is dominated by moderately deformed spinelbearing Iherzolite tectonite, whereas garnet- and/or spinel-bearing mylonitic harzburgite occurs near the border of the massif. In the mylonite, foliation strikes SE-NW with a dip of about $15-50^{\circ} \mathrm{SW}$ and is parallel to the foliation in the overlying granulite (Figure 2). The stretching lineation is subhorizontal with a direction around N150 in both domains. In contrast to the peridotite, kinematic criteria are common in the granulite and show a consistent top-to-the-NW sense of shearing. The granulite-peridotite (crust-mantle) contact is interpreted as a kilometer-scale ductile extensional shear zone with top-to-the-NW sense of shearing with a dextral component. This shear zone is inferred to be at the origin of the unroofing of the mantle rocks [Afiri et al., 2011; Frets et al., 2014]. Similar conclusions have been proposed for the deformation and exhumation of the Ronda peridotites, in Spain [Précigout et al., 2007, 2013].

The Filali unit, located immediately above the granulite, contains metapelitic rocks characterized by a metamorphic grade decreasing toward the top, away from the contact with the peridotite. It comprises, from bottom to top, a migmatitic gneiss, micaschists containing sillimanite-biotite-muscovite, and andalusite-biotite-muscovite-bearing micaschists. The migmatitic layering, micas and sillimanite, and/or micas alone, respectively, define the main foliation (S2), consistent with the foliation direction in the granulite and peridotite (Figure 2). The micaschists contain numerous quartz lenses or veins, locally containing nests of pink andalusite. They form isoclinal folds with axial planes parallel to the main foliation and are boudinaged parallel to S2 in the upper part of the micaschist sequence. In the lower part, they generally cut across S2. The foliation strikes at N110 far from the contact with the granulite and becomes parallel to the crust/mantle contact with a strike of N140-170 close to the granulite. It bears a stretching and mineral lineation that plunges at low angles generally to the E-SE. Consistent top-to-the-NW shear criteria, associated with S2, are widespread in the Filali unit and include sheared quartz lenses, samplescale shear bands, and outcrop-scale shear zones (Figure 3). The progressive rotation of the foliation trajectories toward the crust-mantle contact (Figure 2) is likely related to the top-to-the-NW dextral shearing at the scale of the entire Lower Sebtides [Afiri et al., 2011]. An early foliation, S1, is preserved as inclusion trails in porphyroblasts and described in more detail below. Figure 4 shows the microstructural crystallization/deformation relations, and Figure 5 presents the mineralogical assemblages representative of both S1 and S2 foliation.

Locally semi-brittle high-angle normal faults crosscut the Filali unit and induce strong rotation in the S2 foliation (near Cape Zaouia, Targha, Figure 2). These normal faults cut also the eastern part of the Beni Bousera massif, which is at the origin of (1) the disappearance of the granulite unit at the contact with the peridotites in the eastern part of the Massif (Figure 2, SW of Mter) and (2) the direct contact of the Ghomaride unit with different units: the Upper Sebtides (North and South of Souk el Had, Figure 2), the Lower Sebtides_Filali unit (Cap Zaouia, Figure 2), and the Beni Bousera peridotites (NW of Mter along the coast, Figure 2).

Within this structural framework, the aim of the petrological and geochronological study is to constrain the $\mathrm{P}-\mathrm{T}-\mathrm{t}$ conditions for both the S1 and S2 structures.

\section{Petrology}

In order to decipher the tectonic history of the region and to understand the exhumation of the Beni Bousera peridotites and the juxtaposition with crustal rocks, we have studied the P-T evolution of the peridotites and the surrounding crustal rocks of the Filali unit at different distances from the contact with the peridotites. The objective is to characterize the P-T conditions for both the main regional foliation S2, as well as for the relic S1 foliation in the Filali unit. The P-T evolution of the granulites is not presented here since they have been studied in previous works [see, for example, Bouybaouène et al., 1998; Ruiz Cruz and Sanz de Galdeano, 2014].

Recently, Afiri et al. [2011] have constrained the P-T evolution of the peridotites (from samples PM and PT shown in Figure 2) and only a summary of these results is presented below. The crustal rocks at the contact with the peridotite are aluminous granulites ("kinzigites") [Kornprobst, 1974] that display a migmatitic layering parallel to the main foliation (S2). The synkinematic assemblage contains biotite, prismatic sillimanite, and/or kyanite, K-feldspar, plagioclase, quartz, and small garnet. These rocks have not been studied in detail in the framework of this work. 

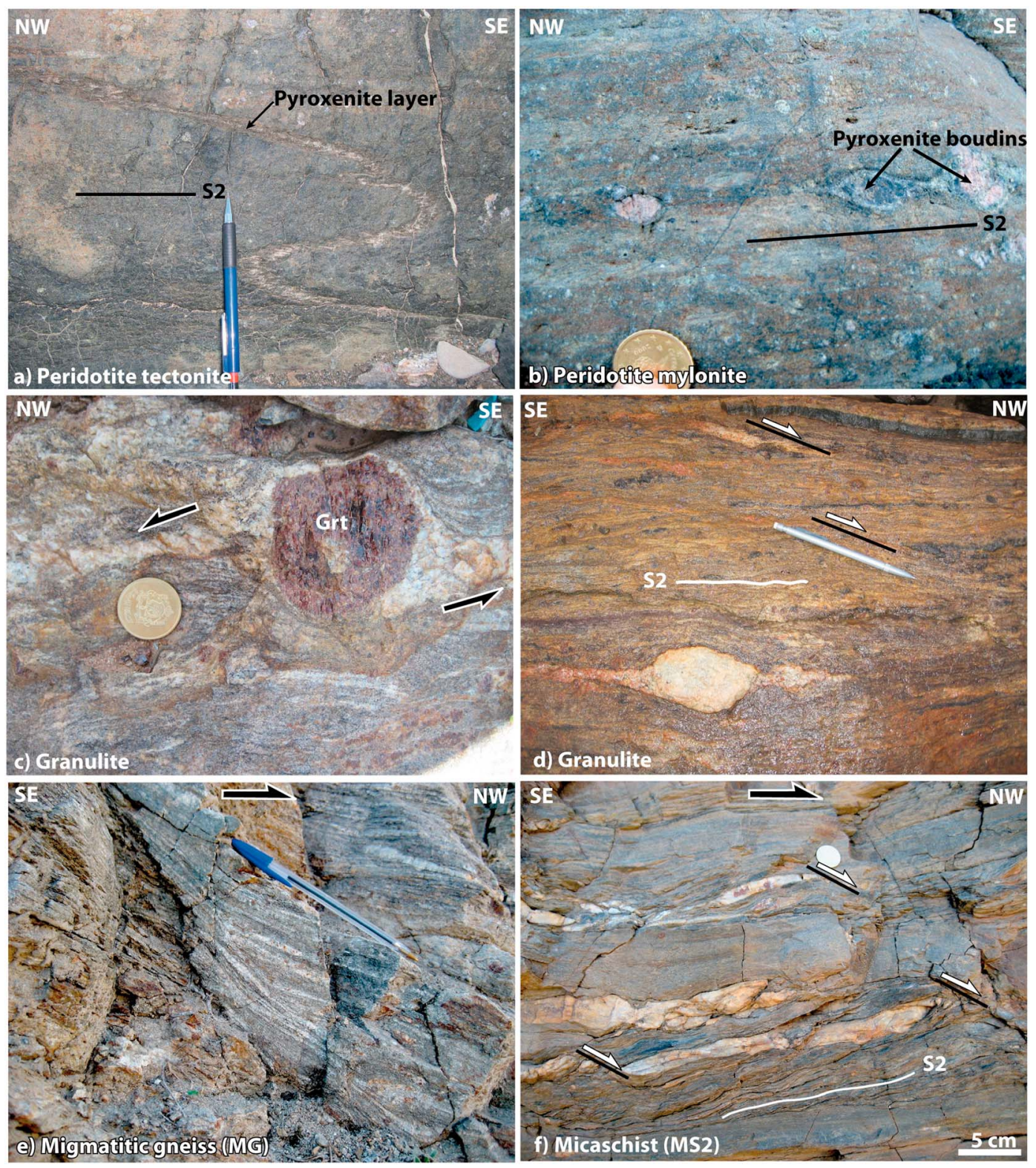

Figure 3. Outcrop photographs. (a) Folding of a layer of pyroxenite in weakly deformed peridotite (tectonite). The main foliation (S2) is parallel to the axial plane of the fold. (b) Boudins of pyroxenite layers in the main foliation (S2) of the mylonitic peridotite. (c) Asymmetric melt-filled crystallization tails around coarse garnet in granulite, indicating top to the NW shear, (d) Penetrative top to the NW shear bands within granulite, coeval with S2 development. (e) Top to the NW shear zone in migmatitic gneiss; (f) Syn-S2 top to the NW shear bands in micaschists, containing andalusite-bearing quartz lenses.

The Filali unit contains metapelitic rocks characterized by a metamorphic grade decreasing toward the top, away from the contact with the peridotite. It comprises, from bottom to top, a migmatitic gneiss, micaschists containing a sillimanite-biotite-muscovite assemblage and andalusite-biotite-muscovite-bearing micaschists (Figure 4). These minerals are contemporaneous with the development of the main foliation (S2), which wraps around crystals associated with the previous fabric S1 (Figure 4). Syn-S1 assemblages comprise, from bottom to top, kyanite-garnet-biotite, kyanite-staurolite-garnet-biotite, staurolite-garnet-biotite, and garnet-biotite (Figure 4). This also witnesses a decrease of the metamorphic grade toward the top of the sequence for this first metamorphic event.

In previous studies [e.g., El Maz and Guiraud, 2001], the metamorphic rocks of the Filali unit have been subdivided into metamorphic zones. Although practical, these divisions are misleading, since they 

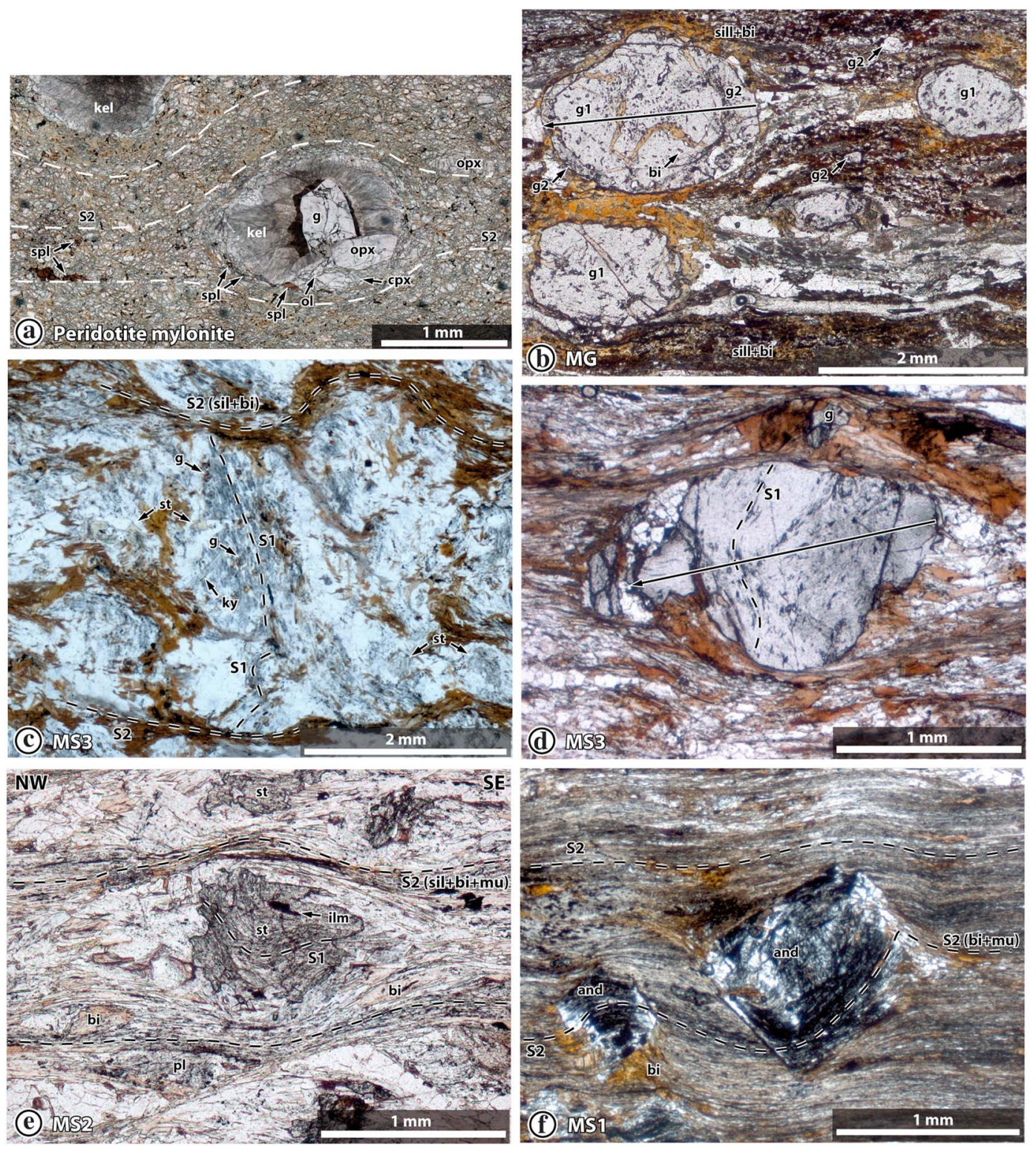

Figure 4. Crystallization/deformation relations. (a) Mylonitic peridotite: kelyphite (kel) surrounds porphyroclasts of garnet, orthopyroxene, clinopyroxene, and spinel, wrapped by a foliated (S2) spinel + olivine-dominated matrix. (b) Migmatitic gneiss: foliation S2 (sillimanite + biotite + garnet 2), parallel to thin leucosomes, wraps around large crystals of garnet 1, surrounded by rims of garnet 2. Long arrow indicates the location of the microprobe profile (Figure 5b). (c) Micaschist MS3: sillimanite + biotite-bearing foliation S2 wrapping around subhedral crystals of plagioclase, which coexists with staurolite, kyanite, and garnet and contains S1 inclusion trails that are at high angle to the matrix foliation S2. (d) Micaschist MS3: anhedral porphyroclast of garnet with S1 inclusion trails at high angle to the matrix foliation S2. Long arrow indicates the location of the microprobe profile (Figure 5a). (e) Micaschist MS2: anhedral staurolite containing curved inclusion trails of S1, discontinuous with the sillimanite + biotite + muscovite-bearing matrix foliation S2. (f) Micaschist MS1: syn-S2 euhedral andalusite crystals.

commonly mix S1 and S2 minerals. To avoid this, the studied rocks are here identified by acronyms with the following meaning, from the bottom to the top of the unit:

MG - migmatitic gneiss with S2 sillimanite + K-feldspar and S1 garnet + kyanite

MS3 - micaschists with S2 sillimanite + muscovite and S1 garnet + staurolite + kyanite

MS2 - micaschists with S2 sillimanite + muscovite and S1 garnet + staurolite

MS1 - micaschists with S2 andalusite and S1 garnet

Figure 5 summarizes the main mineralogical assemblages associated with S1 and S2. 


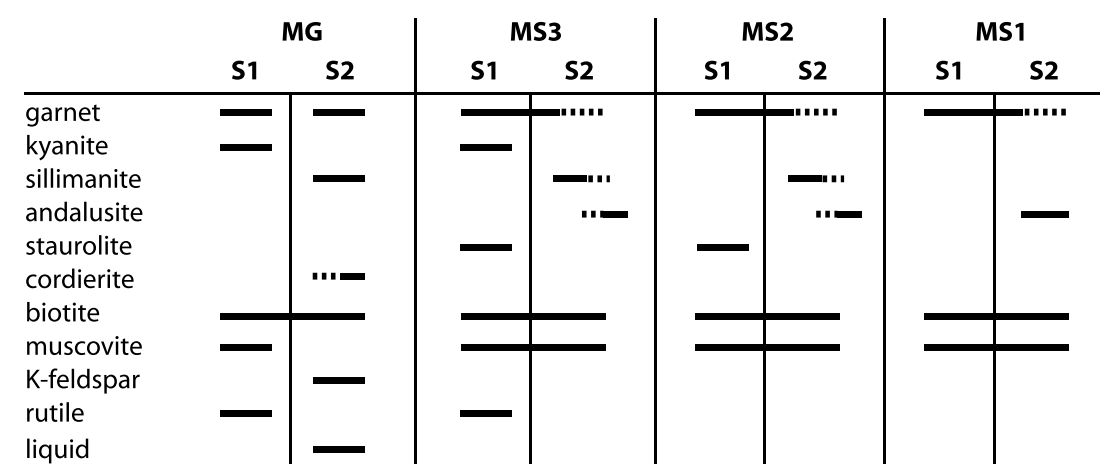

plagioclase, ilmenite and quartz are always present

Figure 5. Main mineralogical assemblages representative of both S1 and S2 foliation in the Filali unit rocks (see Figure 4 for the crystallization/deformation relations).

Bulk rock compositions for selected samples have been analyzed by ICP-AES (Acme, Vancouver, BC V6A 1R6, Canada) and are presented in Table 1. Mineral analyses have been performed with a Cameca SX100 electron microprobe (Microsonde Ouest, Brest, France) operating in the wavelength-dispersive mode. Operating conditions for spot analyses were $15 \mathrm{keV}$ accelerating voltage, $20 \mathrm{nA}$ sample current, and $20 \mathrm{~s}$ counting time on the peak with a beam diameter of $1 \mu \mathrm{m}$. Representative analyses of selected mineral phases are listed in Table 2. Mineral abbreviations follow the THERMOCALC terminology. Other symbols (mol/atomic proportions): $\mathrm{X}_{\mathrm{Fe}}=\mathrm{Fe} /(\mathrm{Fe}+\mathrm{Mg}) ; \mathrm{Ab}=\mathrm{Na} /(\mathrm{Ca}+\mathrm{Na}+\mathrm{K}), \mathrm{An}=\mathrm{Ca} /(\mathrm{Ca}+\mathrm{Na}+\mathrm{K}), \mathrm{Or}=\mathrm{K} /(\mathrm{Ca}+\mathrm{Na}+\mathrm{K}) ; \mathrm{Alm}=\mathrm{Fe} /$ $(\mathrm{Fe}+\mathrm{Mg}+\mathrm{Ca}+\mathrm{Mn}), \quad \operatorname{Prp}=\mathrm{Mg} /(\mathrm{Fe}+\mathrm{Mg}+\mathrm{Ca}+\mathrm{Mn}), \quad \mathrm{Grs}=\mathrm{Ca} /(\mathrm{Fe}+\mathrm{Mg}+\mathrm{Ca}+\mathrm{Mn}), \quad \mathrm{Sps}=\mathrm{Mn} /(\mathrm{Fe}+\mathrm{Mg}+\mathrm{Ca}$ $+\mathrm{Mn}) ; \mathrm{Ms}=\mathrm{K} /(\mathrm{Na}+\mathrm{Ca}+\mathrm{K}), \mathrm{Pg}=\mathrm{Na} /(\mathrm{Na}+\mathrm{Ca}+\mathrm{K}) ; \mathrm{Al}^{\mathrm{VI}}=$ octahedral $\mathrm{Al}$ in phyllosilicates $=$ atomic $\mathrm{Al}+\mathrm{Si}-4$; pfu-per formula unit. " $\rightarrow$ " denote core-to-rim evolution.

P-T conditions for the samples from the Filali unit were calculated using the software THERMOCALC v. 3.3 [Powell and Holland, 1985, 1988] and the internally consistent thermodynamic data set 5.5 [Holland and Powell, 1998, November 2003 upgrade]. First, P-T calculations were carried out using the multiequilibrium thermobarometric "average PT" (avPT) mode [Powell and Holland, 1988] and the compositions of minerals inferred to be in equilibrium. The activities of the mineral end-members were calculated with the program AX (Holland and Powell, 2000 in Powell and Holland [2002]; http://www.esc.cam.ac.uk/research/researchgroups/research-projects/tim-hollands-software-pages/ax). The results are summarized in Table 3. Furthermore, P-T pseudosections have been calculated in the model system MnNCKFMASHTO. References to the activity-composition models used are: white micas [Coggon and Holland, 2002], plagioclase [Holland and Powell, 2003], ilmenite-hematite [White et al., 2000], and biotite and melt [White et al., 2007]. Mixing models for other solid solutions are based on Holland and Powell [1998] and extended to the Mn-bearing system when necessary [Le Bayon et al., 2006]. Nonideality parameters are from Holland and Powell [1998] and the THERMOCALC documentation [Powell and Holland, 2002].

\subsection{Peridotites}

Spinel-bearing Iherzolite tectonites in the core of the massif display orthopyroxene and clinopyroxene porphyroclasts in a weakly foliated coarse-grained granoblastic matrix, containing olivine, and subordinate orthopyroxene, clinopyroxene, and spinel. Harzburgite mylonites, which prevail near the border of the massif, comprise a fine-grained matrix that displays a foliation well defined by the flattening of olivine and spinel crystals (and also contains subordinate clinopyroxene and orthopyroxene). The foliation wraps around porphyroclasts of orthopyroxene, garnet, and locally clinopyroxene. Garnet forms anhedral crystals generally surrounded by a layered kelyphitic corona (Figure 4a). Using standard geothermobarometry, Afiri et al. [2011] concluded that the deformation related to the transition from tectonite to mylonite occurred during decompression from $\approx 22 \mathrm{kbar}, 1050^{\circ} \mathrm{C}$ to $\approx 9-15 \mathrm{kbar}, 800^{\circ} \mathrm{C}$.

\subsection{Filali Metapelites}

4.2.1. MG-Petrography and Mineral Chemistry

The migmatitic gneiss MG forms the base of the Filali unit, immediately overlying the migmatitic aluminous granulites (not studied here), which surround the peridotite body. It displays a migmatitic layering parallel to S2. 
Table 1. Bulk-Rock Compositions Used for the Calculation of the Phase Diagrams-Analyzed (Given in Weight \%) and Converted to the Model System MnNCKFMASHTO (in mol \%) ${ }^{a}$

\begin{tabular}{|c|c|c|c|c|}
\hline Sample & MS1 & MS2 & MS3 & MG \\
\hline Reference No. & $23 \mathrm{~B}$ & $26 B$ & $34 \mathrm{~B}$ & 18 \\
\hline \multicolumn{5}{|c|}{$w t \%$} \\
\hline $\mathrm{SiO}_{2}$ & 64.19 & 56.86 & 55.39 & \\
\hline $\mathrm{Al}_{2} \mathrm{O}_{3}$ & 16.11 & 21.38 & 23.99 & \\
\hline $\mathrm{Fe}_{2} \mathrm{O}_{3}$ & 6.74 & 7.33 & 8.90 & \\
\hline $\mathrm{MgO}$ & 1.65 & 1.88 & 2.03 & \\
\hline $\mathrm{CaO}$ & 1.63 & 0.75 & 1.41 & \\
\hline $\mathrm{Na}_{2} \mathrm{O}$ & 1.17 & 1.44 & 0.93 & \\
\hline $\mathrm{K}_{2} \mathrm{O}$ & 3.14 & 5.05 & 3.21 & \\
\hline $\mathrm{TiO}_{2}$ & 0.83 & 0.94 & 1.02 & \\
\hline $\mathrm{P}_{2} \mathrm{O}_{5}$ & 0.12 & 0.16 & 0.22 & \\
\hline $\mathrm{MnO}$ & 0.12 & 0.07 & 0.15 & \\
\hline $\mathrm{Cr}_{2} \mathrm{O}_{3}$ & 0.01 & 0.02 & 0.02 & \\
\hline LOI & 4.10 & 3.90 & 2.50 & \\
\hline Total & 99.81 & 99.78 & 99.77 & \\
\hline \multicolumn{5}{|c|}{$\mathrm{mol} \%$} \\
\hline $\mathrm{SiO}_{2}$ & 74.04 & 67.87 & 65.7 & 58.06 \\
\hline $\mathrm{Al}_{2} \mathrm{O}_{3}$ & 10.95 & 15.04 & 16.77 & 19.31 \\
\hline $\mathrm{FeO}$ & 5.86 & 6.59 & 7.94 & 9.78 \\
\hline $\mathrm{MgO}$ & 2.84 & 3.35 & 3.59 & 3.76 \\
\hline $\mathrm{CaO}$ & 1.82 & 0.70 & 1.42 & 0.47 \\
\hline $\mathrm{Na}_{2} \mathrm{O}$ & 1.31 & 1.67 & 1.07 & 0.57 \\
\hline $\mathrm{K}_{2} \mathrm{O}$ & 2.31 & 3.84 & 2.43 & 4.14 \\
\hline $\mathrm{TiO}_{2}$ & 0.72 & 0.84 & 0.91 & 3.54 \\
\hline $\mathrm{MnO}$ & 0.12 & 0.07 & 0.15 & 0.10 \\
\hline 0 & 0.03 & 0.03 & 0.02 & 0.27 \\
\hline Total & 100.00 & 100.00 & 100.00 & 100.00 \\
\hline
\end{tabular}

${ }^{\mathrm{a}}$ The composition of the sample MG was calculated from measured mineral modes and compositions.
Thin leucosomes (in general $<1 \mathrm{~cm}$ thick) are dominated by plagioclase and quartz and also contain subordinate K-feldspar and locally garnet, biotite, fibrolite, and cordierite. The melanosomes comprise syn- $\mathrm{S}_{2}$ fibrolitic sillimanite, biotite $\left(\mathrm{X}_{\mathrm{Fe}}=0.64-0.66, \mathrm{Al}^{\mathrm{VI}}=0.32-0.46\right.$, and $\mathrm{Ti}=0.21-0.26 \mathrm{pfu}$ ), plagioclase (Ab4648, An53-51, and Or1) and small subhedral crystals of garnet $(<1.5 \mathrm{~mm}$; Alm73-77, Prp12-7, Grs7-4, Sps7-11, and $\left.\mathrm{X}_{\mathrm{Fe}}=0.87-0.91\right)$ together with quartz and ilmenite. Cordierite $\left(X_{\mathrm{Fe}}=0.56-0.58\right)$ commonly surrounds small clusters of fibrolite or garnet crystals. It is not clear whether it crystallized syn-S2 or slightly later. The foliation wraps around rare large crystals of plagioclase and garnet (Figure 4b). Plagioclase contains inclusions of quartz, biotite, ilmenite, and locally kyanite and muscovite. Garnet forms anhedral, optically zoned crystals (up to $5 \mathrm{~mm}$ ) with inclusions of biotite, plagioclase, rutile, ilmenite, apatite, and quartz. Inclusions are concentrated at the interface between the large core (approximately $80 \%$ of the diameter) of the crystals and the rim. In the core, they locally define an internal foliation, interpreted as the trace of S1, always at high angle and discontinuous with S2. Rare tiny inclusions in the rim (mostly ilmenite and biotite) are generally parallel or at low angle to S2. These garnet crystals display a chemical zoning (Figure 6). The large core displays a smooth bell-shaped rimward decrease of spessartine and $\mathrm{X}_{\mathrm{Fe}}$ and an increase of grossular, followed by an increase of spessartine and $\mathrm{X}_{\mathrm{Fe}}$ and a decrease of grossular (Alm $74 \rightarrow 78 \rightarrow 73$, Prp $7 \rightarrow 11$, Grs $5 \rightarrow 8 \rightarrow 5$, Sps $13 \rightarrow 4 \rightarrow 10$, and $\mathrm{X}_{\mathrm{Fe}}=0.91 \rightarrow 0.87 \rightarrow 0.89$ ). The rim displays a contrasting zoning with a flat inner part and zoned outermost $\operatorname{rim}\left(\right.$ Alm77 $\rightarrow 78$, Prp $14 \rightarrow 6$, Grs $8 \rightarrow 4 \rightarrow 6$, Sps $2 \rightarrow 11$, and $X_{\mathrm{Fe}}=0.85 \rightarrow 0.93$ ). This composition range is similar to that of the small garnet crystals.

In summary, it is inferred that the rock had an assemblage involving garnet, kyanite, biotite, plagioclase, muscovite, quartz, ilmenite, and rutile during the development of S1. An assemblage containing a second generation of garnet in equilibrium with sillimanite, biotite, plagioclase, K-feldspar, quartz, ilmenite, and possibly cordierite crystallized during the development of the major regional foliation S2. The compositional difference between the two types of garnet, as well as the contrasting character of the orientation of their inclusions, suggests that they developed in distinct tectonometamorphic settings, under different P-T conditions. The zoning of the outer parts of both the core and the rim of the large garnets (and in particular the increase of spessartine) are interpreted as the result of a diffusional reequilibration due to a partial resorption of the crystals following the development of S1 and S2, respectively. This suggests that the rock recorded a polycyclic evolution.

\subsubsection{MG-P-T Conditions}

Two P-T pseudosections have been calculated for the composition of the sample MG (BB06-18) (Table 1), reconstructed from measured mineral modes and compositions, in the model system MnNCKFMASHTO (Figures $7 \mathrm{a}$ and $7 \mathrm{~b}$ ). The first diagram (Figure 7a) is used to estimate the conditions of the syn-S1 


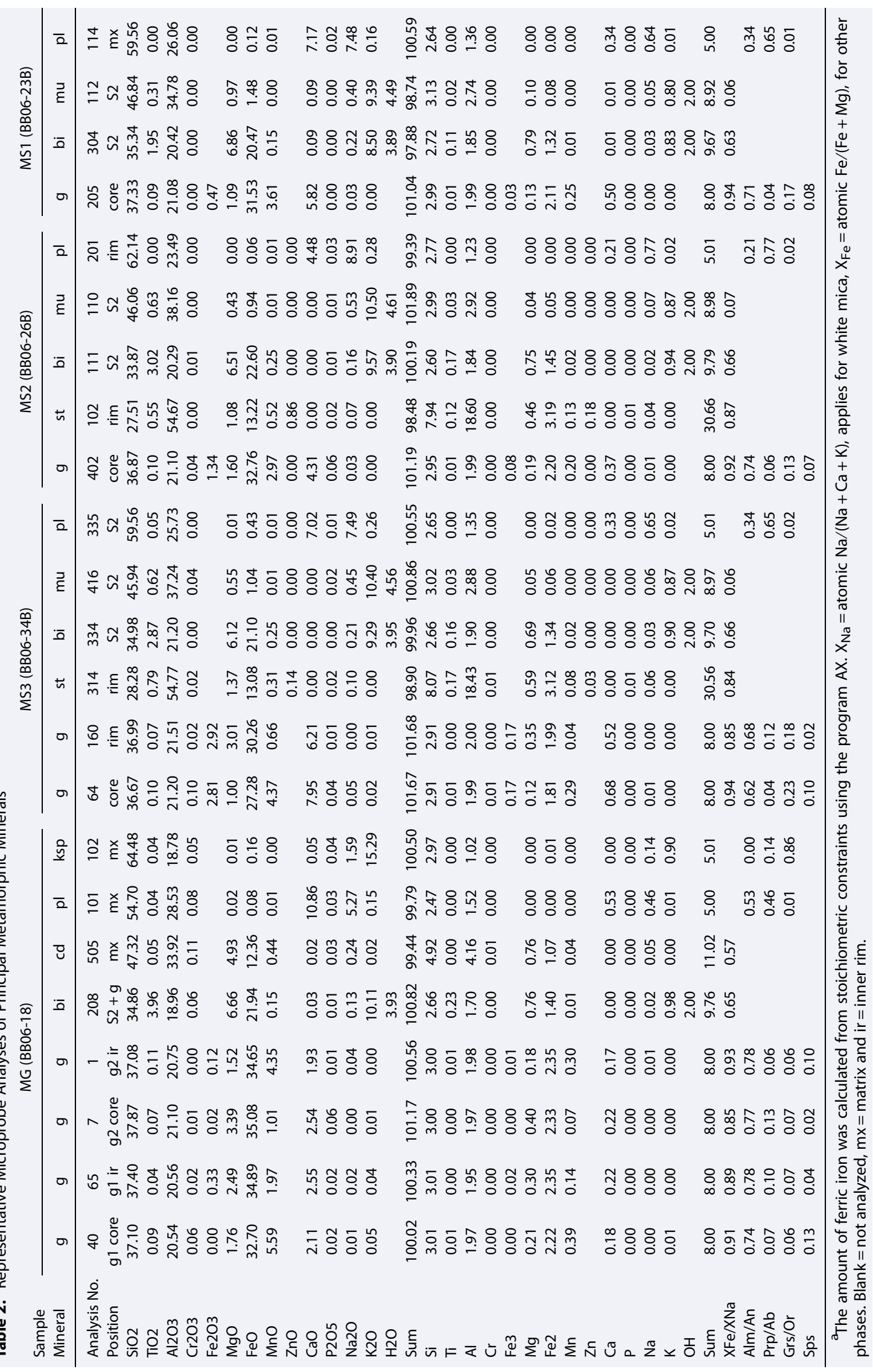


Table 3. Summary of the THERMOCALC Average P-T Calculations (Values in Bold) on Selected Samples ${ }^{\text {a }}$

\begin{tabular}{|c|c|c|c|c|c|c|c|c|}
\hline \multicolumn{7}{|c|}{ Micaschists } & \multirow{2}{*}{\multicolumn{2}{|c|}{$\begin{array}{c}\text { Migmatitic Gneiss } \\
\text { MG }\end{array}$}} \\
\hline \multirow{2}{*}{$\begin{array}{l}\text { Sample } \\
\text { End-Member }\end{array}$} & \multicolumn{2}{|c|}{ MS1 } & \multicolumn{2}{|c|}{ MS2 } & \multicolumn{2}{|c|}{ MS3 } & & \\
\hline & $a$ & $\mathrm{SD}(a) / a$ & $a$ & $\mathrm{SD}(a) / a$ & $a$ & $\mathrm{SD}(a) / a$ & $a$ & $\mathrm{SD}(a) / a$ \\
\hline \multicolumn{9}{|l|}{ Garnet } \\
\hline py & 0.00068 & 0.75 & 0.00059 & 0.76 & 0.00167 & 0.70 & 0.00052 & 0.76 \\
\hline gr & 0.00063 & 0.75 & 0.00091 & 2.00 & 0.00440 & 2.00 & 0.00030 & 1.56 \\
\hline alm & 0.36 & 0.15 & 0.35 & 0.15 & 0.32 & 0.15 & 0.40 & 0.15 \\
\hline spss & 0.0014 & 0.71 & 0.0014 & 0.71 & 0.000079 & 0.82 & 0.0017 & 0.69 \\
\hline \multicolumn{9}{|l|}{ Staurolite } \\
\hline mst & & & 0.0008 & 2.00 & 0.0012 & 1.59 & & \\
\hline fst & & & 0.48 & 0.20 & 0.44 & 0.20 & & \\
\hline \multicolumn{9}{|l|}{ Biotite } \\
\hline phl & 0.023 & 0.43 & 0.016 & 0.46 & 0.020 & 0.44 & 0.015 & 0.46 \\
\hline ann & 0.043 & 0.38 & 0.079 & 0.29 & 0.061 & 0.33 & 0.069 & 0.31 \\
\hline east & 0.026 & 0.42 & 0.025 & 0.43 & 0.03 & 0.41 & 0.02 & 0.42 \\
\hline \multicolumn{9}{|l|}{ Muscovite } \\
\hline $\mathrm{mu}$ & 0.71 & 0.10 & 0.77 & 0.10 & 0.78 & 0.10 & & \\
\hline cel & 0.012 & 0.82 & 0.005 & 2.22 & & & & \\
\hline fcel & & & 0.005 & 2.08 & & & & \\
\hline \multicolumn{9}{|l|}{ Ilmenite } \\
\hline ilm & 0.86 & 0.05 & 0.92 & 0.05 & 0.92 & 0.05 & 0.91 & 0.05 \\
\hline pnt & 0.042 & 0.28 & 0.033 & 0.30 & 0.016 & 0.63 & 0.024 & 0.42 \\
\hline geik & 0.009 & 1.15 & 0.0130 & 0.77 & 0.0034 & 2.94 & 0.0028 & 3.57 \\
\hline \multicolumn{9}{|l|}{ Plagioclase } \\
\hline an & 0.51 & 0.07 & 0.36 & 0.12 & 0.54 & 0.06 & 0.72 & 0.05 \\
\hline Other & $\mathrm{q}, \mathrm{H}_{2} \mathrm{O}$ & & $\mathrm{q}, \mathrm{H}_{2} \mathrm{O}$ & & $\mathrm{ky}, \mathrm{ru}, \mathrm{q}, \mathrm{H}_{2} \mathrm{O}$ & & $\mathrm{ky}, \mathrm{ru}, \mathrm{q}, \mathrm{H}_{2} \mathrm{O}$ & \\
\hline Results & & SD & & SD & & SD & & SD \\
\hline $\mathrm{T}\left({ }^{\circ} \mathrm{C}\right)$ & 516 & 99 & 568 & 50 & 624 & 20 & 705 & 117 \\
\hline$P$ (kbar) & 5.4 & 1.4 & 6.1 & 1.4 & 7.4 & 1.0 & 7.9 & 1.2 \\
\hline Correlation & 0.826 & & -0.057 & & 0.177 & & 0.558 & \\
\hline fit & 0.67 & $(1,54)$ & 0.81 & $(1,42)$ & 0.84 & $(1,42)$ & 0.95 & $(1,54)$ \\
\hline$N(R)$ & 6 & & 9 & & 9 & & 6 & \\
\hline
\end{tabular}

${ }^{a}$ Indicated uncertainties (SD) are $1 \sigma . N(R)=$ number of independent reactions used. Abbreviations are those used by THERMOCALC. For $95 \%$ confidence, the value of "fit" must be lower than the number that follows in parentheses.

assemblage. It was calculated with the amount of $\mathrm{H}_{2} \mathrm{O}(9.09 \mathrm{~mol} \%)$ set so that the rock be just fluid saturated at the solidus. It suggests equilibration at approximately $8.5 \mathrm{kbar}, 670^{\circ} \mathrm{C}$, corresponding to the g-ky-bi-pl-ru stability field. This is compatible with the results of the THERMOCALC multiequilibrium thermobarometric calculations (avPT), which yield $7.9 \pm 1.2 \mathrm{kbar}, 705 \pm 117^{\circ} \mathrm{C}$ (Table 3).

The migmatitic character of the sample suggests that partial melting occurred during the second tectonometamorphic event. The available amount of $\mathrm{H}_{2} \mathrm{O}$ plays an important role for phase relations involving silicate liquid. In the present case, this amount was estimated from a $\mathrm{T}-\mathrm{M}_{\mathrm{H} 2 \mathrm{O}}$ pseudosection (not presented here) using the presence of the observed assemblage at the solidus as a constraint. The second diagram (Figure 7b) is a P-T pseudosection calculated with this estimated amount of $\mathrm{H}_{2} \mathrm{O}(3.45 \mathrm{~mol} \%)$. The assemblage $\mathrm{g}$-sill-ksp-bi-pl-q-ilm is stable at the solidus at approximately $730^{\circ} \mathrm{C}$ and between 4 and $7 \mathrm{kbar}$. If cordierite is considered in equilibrium with this syn-S2 assemblage, the equilibration conditions are at the low-pressure side of this interval, at approximately $4 \mathrm{kbar}, 730^{\circ} \mathrm{C}$. At these conditions the calculated compositions of garnet and plagioclase agree with the observed ones (Figure 7b).

\subsubsection{MS3-Petrography and Mineral Chemistry}

Macroscopically, the micaschists are fine-grained rocks, dominated by biotite, sillimanite, feldspar, and quartz. They contain numerous lenses and veins of quartz and pink andalusite, commonly crosscutting, but locally stretched and boudinaged in the main foliation. Microscopically, the main foliation S2 in the MS3 micaschists is defined by the preferred orientation of biotite $\left(\mathrm{X}_{\mathrm{Fe}}=0.63-0.66, \mathrm{Al}^{\mathrm{VI}}=0.44-0.55\right.$, and $\mathrm{Ti}=0.09-0.16 \mathrm{pfu}$ ), commonly intergrown with fibrolitic sillimanite, muscovite (Ms94-95, Pg6-5, and $\mathrm{Si}=3.02-3.09 \mathrm{pfu}$ ), plagioclase (Ab60-65, An39-34, and Or1), quartz, graphite, and ilmenite. It wraps 


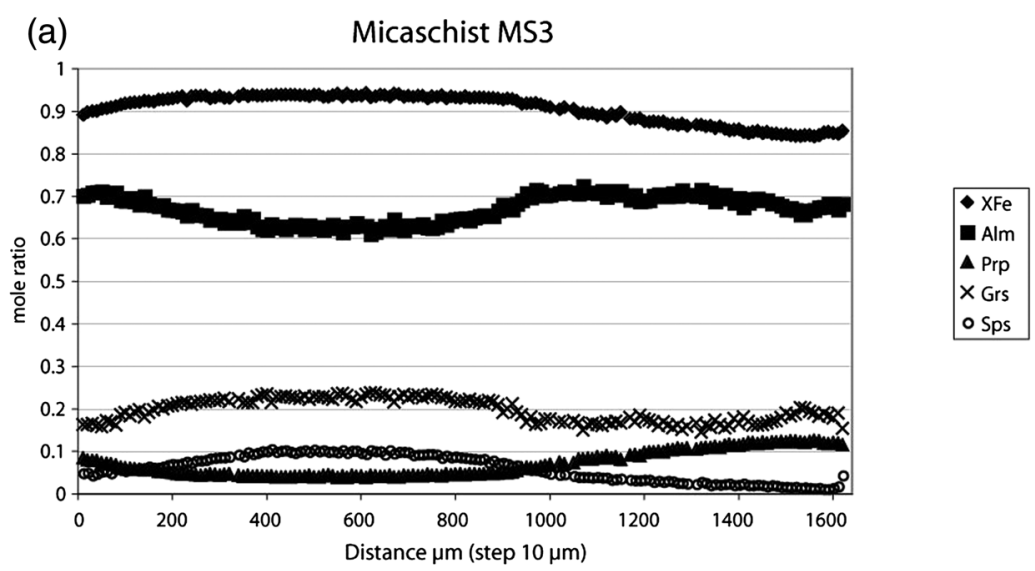

(b)

Migmatitic gneiss (MG)

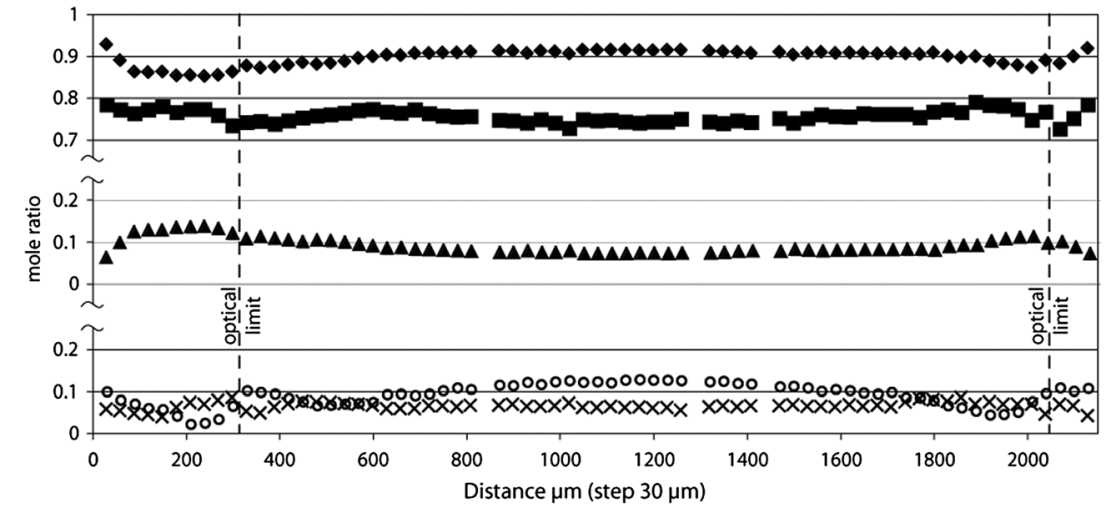

Figure 6. (a) Chemical zoning profiles of garnet from the micaschist MS3 and (b) the migmatitic gneiss (MG). Location of profiles indicated in Figure 4.

around subhedral to anhedral crystals of plagioclase (2.5-3.5 mm; Ab64-67, An29-34, and Or2-4), staurolite $\left(2-3 \mathrm{~mm} ; \mathrm{X}_{\mathrm{Fe}}=0.83-0.86 ; \mathrm{Ti}, \mathrm{Mn}\right.$, and $\mathrm{Zn}=0.13-0.18,0.07-0.10$, and 0-0.04 pfu, respectively) and garnet (Figures $4 c$ and $4 d$ ). These crystals contain inclusions of quartz, ilmenite, rutile, biotite, muscovite, graphite, and locally kyanite, which define and internal foliation, locally sigmoidal, which is generally at high angles and discontinuous with S2 (Figures $4 \mathrm{c}$ and $4 \mathrm{~d}$ ). Garnet displays regular chemical zoning (Figure 6) characterized by a rimward decrease in spessartine, grossular, and $X_{\mathrm{Fe}}$ (Alm62 $\rightarrow 72$, Prp3 $\rightarrow 9$, Grs $24 \rightarrow 15$, $\mathrm{Sps} 10 \rightarrow 1$, and $\mathrm{X}_{\mathrm{Fe}}=0.94 \rightarrow 0.84$ ). A slight increase in spessartine and $\mathrm{X}_{\mathrm{Fe}}$ is locally observed at the outermost $\operatorname{rim}\left(\mathrm{Sps} 5, \mathrm{X}_{\mathrm{Fe}}=0.86\right)$.

Our interpretation is that the assemblage contemporaneous with the development of the main foliation S2 contained sillimanite, biotite, muscovite, plagioclase, ilmenite, and quartz, possibly in equilibrium with garnet rims. This assemblage overprints an earlier assemblage, which contained garnet, staurolite, kyanite, biotite, muscovite, plagioclase, ilmenite, rutile, and quartz. The sigmoidal character of the inclusions in garnet and staurolite suggest that the crystallization of this assemblage was contemporaneous with the development of the earlier foliation S2. Garnet zoning is interpreted as growth zoning, probably associated with the prograde part of the early metamorphic evolution. Thin outer rims reflect diffusional zoning due to limited resorption of garnet.

\subsubsection{MS3-P-T Conditions}

A P-T pseudosection has been calculated in the model system MnNCKFMASHTO for the analyzed bulk composition of the sample MS3 (BB06-34B) (Table 1 and Figure 8). It has been contoured with compositional isopleths for garnet, biotite, and plagioclase in order to obtain tighter constraints on the equilibration conditions and on the P-T path followed by the sample (Figure 8a). Using the contents of spessartine and grossular in the garnet core (Grs23, Sps10), it is inferred that it crystallized at 
a) MG

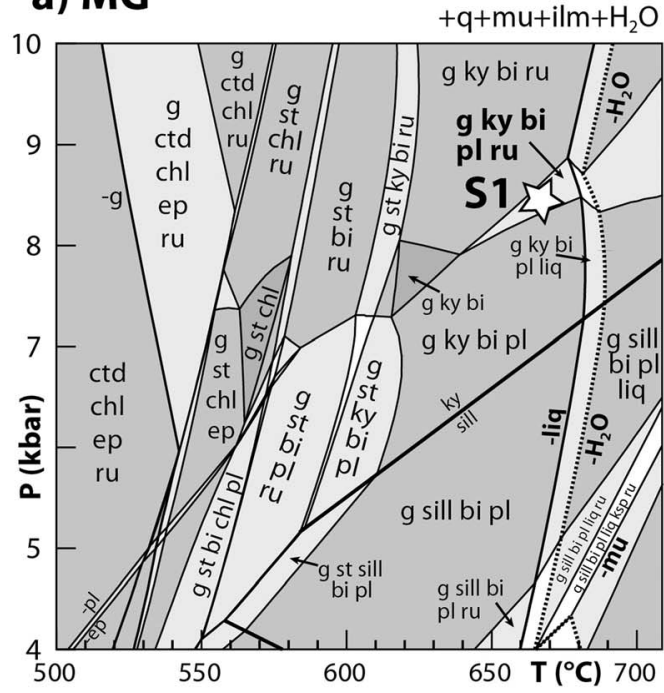

c) MS2

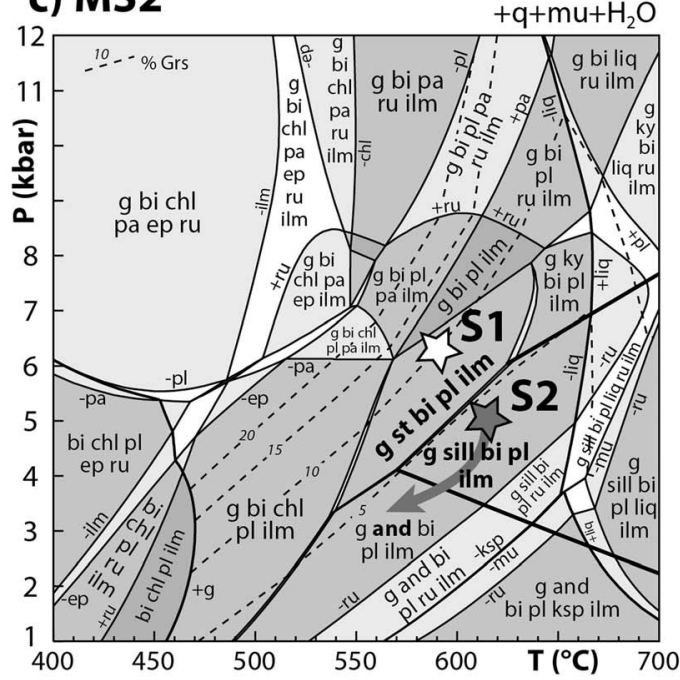

b) MG

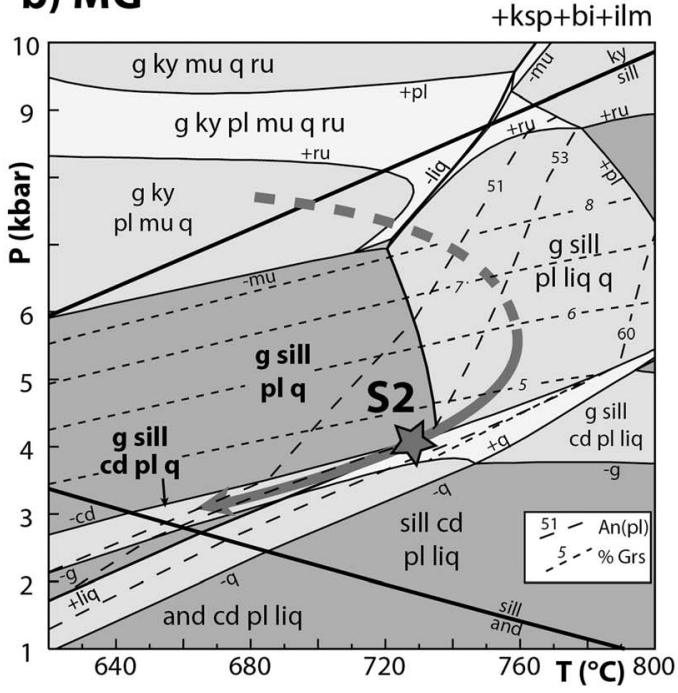

d) MS1

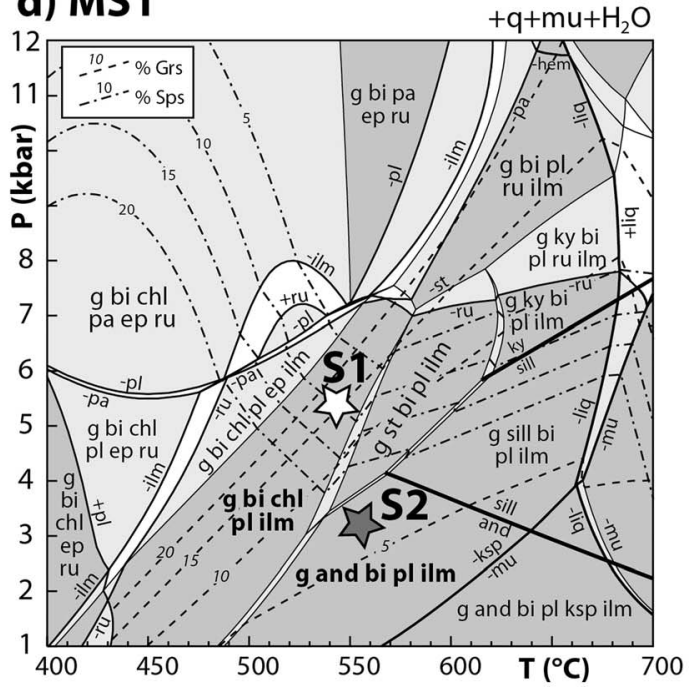

Figure 7. P-T pseudosections and selected compositional isopleths for the bulk compositions (Table 1) of samples (a and b) MG, (c) MS2, and (d) MS1. See text for details.

approximately $5.8 \mathrm{kbar}, 520^{\circ} \mathrm{C}$. The syn-S1 assemblage suggests equilibration in the field g-ky-st-bi-pl-ru-ilm $\left(6-8 \mathrm{kbar}, 600-620^{\circ} \mathrm{C}\right)$. The isopleths corresponding to the composition of the garnet $\operatorname{rim}(\mathrm{Grs} 15, \mathrm{Sps}<3)$ suggest that the equilibration occurred in the upper part of the field, at approximately $8 \mathrm{kbar}, 610^{\circ} \mathrm{C}$. This value is compatible with the results of the THERMOCALC multiequilibrium thermobarometric calculations (avPT), which yield $7.4 \pm 1.0 \mathrm{kbar}, 624 \pm 20^{\circ} \mathrm{C}$ (Table 3).

The syn-S2 assemblage equilibrated in the stability field g-sil-bi-pl-ilm. Compositional isopleths corresponding to the composition of the matrix plagioclase and biotite suggest that this equilibration occurred at approximately $5.8 \mathrm{kbar}, 660^{\circ} \mathrm{C}$. Multiequilibrium thermobarometric calculations (avPT) with THERMOCALC yielded similar values: $5.9 \pm 1.5 \mathrm{kbar}, 670 \pm 100^{\circ} \mathrm{C}$ (Table 3). The presence of andalusite-bearing veins and lenses suggests that the main foliation was at least partly active in the andalusite stability field, suggesting decompression and cooling.

\subsubsection{MS2-Petrography and Mineral Chemistry}

Macroscopically, the micaschists are fine-grained, dominated by biotite, muscovite, and quartz. They contain numerous lenses and veins of quartz-containing crystals of pink andalusite, stretched and boudinaged in the main foliation (Figure 3f). Locally, the veins are folded together with the main foliation by open to close folds, 


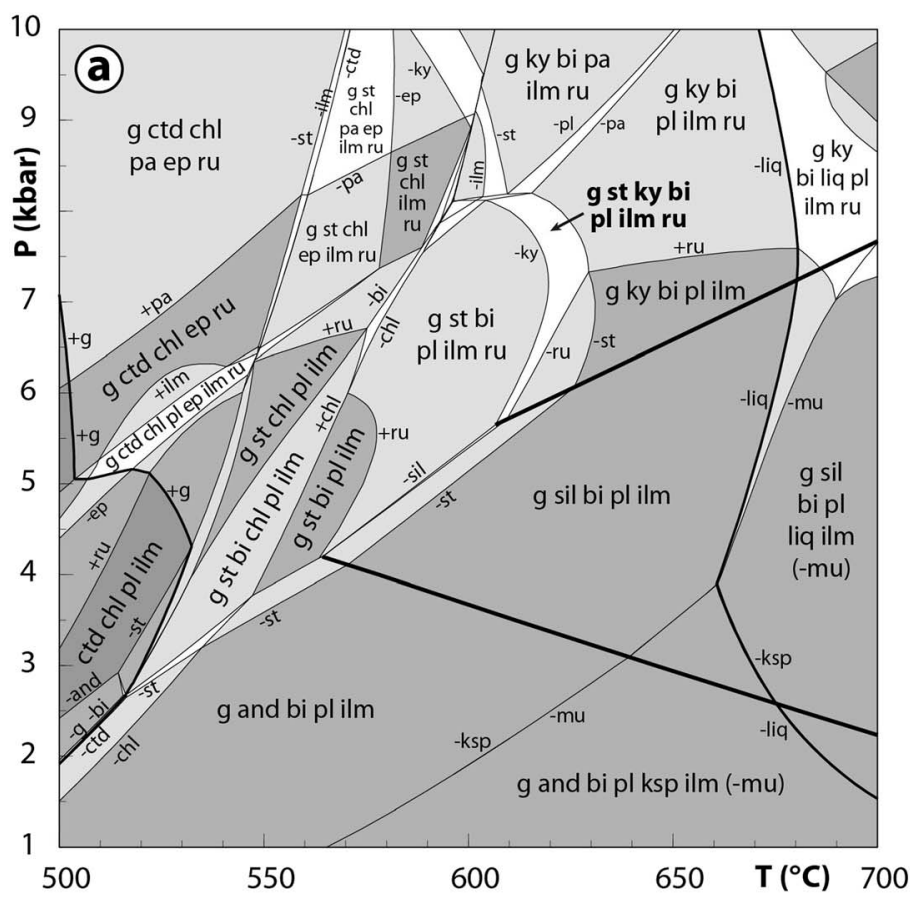

MS3

MnNCKFMASHTO

$+\mathrm{q}+\mathrm{mu}+\mathrm{H}_{2} \mathrm{O}$
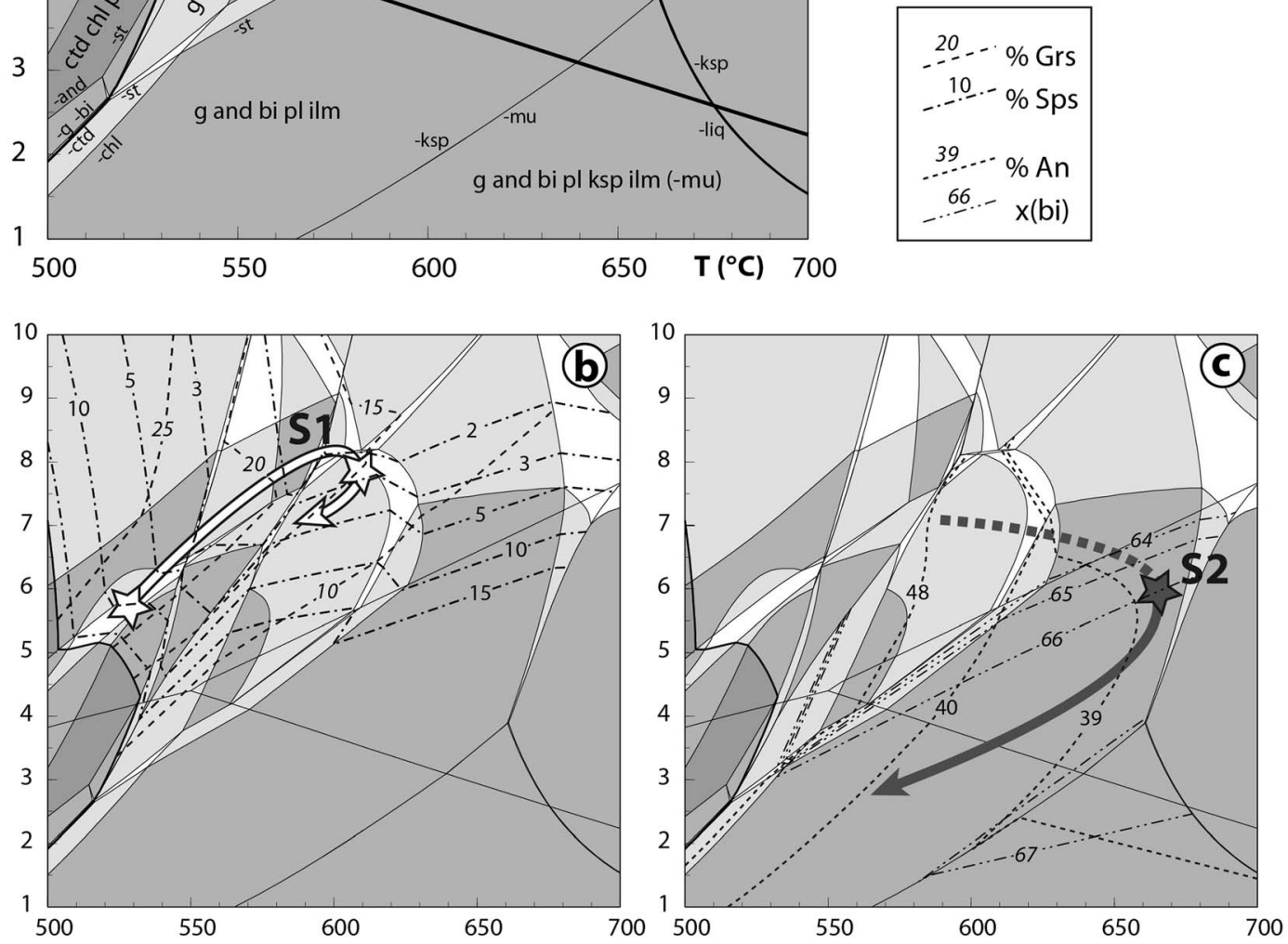

Figure 8. (a) P-T pseudosection for sample MS3. $\mathrm{H}_{2} \mathrm{O}$ fluid is considered in excess, and quartz and muscovite are present in all fields, excepting in the high-temperature low-pressure part of the diagram (beyond the line marked "-mu"). (b) Simplified pseudosection with calculated compositional isopleths of the grossular and spessartine content of garnet used to infer the prograde syn-S1 P-T path. (c) Simplified pseudosection with calculated compositional isopleths of the anorthite proportion of plagioclase and the $\mathrm{X}_{\mathrm{Fe}}$ ratio in biotite, $x(\mathrm{bi})$, used to constrain the peak conditions during the development of the $\mathrm{S} 2$ fabric. See text for further details.

the axial plane of which is subparallel to the main foliation. The main foliation $\mathrm{S} 2$ is defined by the preferred orientation of biotite $\left(\mathrm{X}_{\mathrm{Fe}}=0.62-0.70, \mathrm{Al}^{\mathrm{VI}}=0.39-0.52\right.$, and $\mathrm{Ti}=0.15-0.25 \mathrm{pfu}$ ), muscovite (Ms92-93, Pg8-7, and $\mathrm{Si}=3.02 \mathrm{pfu}$ ), plagioclase (Ab74-78, An24-21, and Or1-2), sillimanite, quartz, graphite, and ilmenite. It wraps around anhedral crystals of plagioclase $(0.4-0.6 \mathrm{~mm}$; Ab74-82, An24-16, Or1-2) and staurolite (0.7-1.5 mm, $\mathrm{X}_{\mathrm{Fe}}=0.86-0.87 ; \mathrm{Ti}, \mathrm{Mn}$, and $\mathrm{Zn}=0.1-0.15,0.13-0.14,0.12-0.18 \mathrm{pfu}$, respectively). These crystals contain inclusions of graphite, quartz, muscovite, biotite, ilmenite, and locally rutile. The inclusions define a curved, sigmoidal, or folded internal schistosity, commonly at high angles to and discontinuous with the main foliation S2 (Figure 4e). Staurolite is locally mantled by andalusite or 
replaced by large unoriented crystals of muscovite and biotite. Rare crystals of garnet (up to $1 \mathrm{~mm}$; Alm7275, Prp6-7, Grs9-13, Sps7-12, and $\mathrm{X}_{\mathrm{Fe}}=0.91-0.93$ ) are strongly anhedral and wrapped by the foliation. No systematic chemical zoning was observed. They contain inclusions of graphite, muscovite, biotite, plagioclase, quartz, and ilmenite. Unoriented crystals of muscovite and biotite develop at the expense of garnet rims.

It is inferred that the major foliation S2 developed in the stability domain of the assemblage sill-bi-mu-pl-ilm$q \pm g$. The earlier assemblage, containing staurolite, garnet, plagioclase, biotite, muscovite, and ilmenite, developed during the formation of the $\mathrm{S} 1$ foliation, as suggested by the sigmoidal inclusion trails. The lack of systematic chemical zoning in garnet is attributed to probable partial diffusional reequilibration of the garnet interior.

4.2.6. MS2-P-T Conditions

In the P-T pseudosection calculated for the composition of the sample MS2 (BB06-26B) (Table 1 and Figure 7c), the $\mathrm{S} 1$ assemblage is stable in the field g-st-bi-pl-ilm at $5-8 \mathrm{kbar}, 550-630^{\circ} \mathrm{C}$. The position of the isopleths of the amount of grossular, known to be relatively insensitive to late reequilibration, suggests equilibration in the LT-HP part of the field. Consistently, multiequilibrium thermobarometric calculations (avPT) with THERMOCALC yield $6.1 \pm 1.4 \mathrm{kbar}, 568 \pm 50^{\circ} \mathrm{C}$ (Table 3 ) for the $\mathrm{S} 1$ assemblage. The matrix (S2) assemblage best fits in the stability field g-sill-bi-pl-ilm, at $4-7 \mathrm{kbar}, 570-660^{\circ} \mathrm{C}$. The syn-S2 formation of the andalusitebearing quartz veins suggests that the main foliation developed during progressive decompression and cooling from the sillimanite to the andalusite stability field.

\subsubsection{MS1-Petrography and Mineral Chemistry}

Macroscopically, the very fine-grained dark micaschists MS1 are dominated by biotite, muscovite, quartz, and graphite, and contain millimetric crystals of garnet and dark (graphite-coated) millimetric prisms of andalusite. The main foliation is parallel to a layering marked by alternating mica- and quartz-rich layers several milimeters to several centimeters thick. Lenses and veins of quartz-containing crystals of pink andalusite are stretched and boudinaged in the main foliation and locally folded with the foliation by open to close folds, the axial plane of which is subparallel to the main foliation. The main foliation S2 is defined by the preferred orientation of biotite $\left(\mathrm{X}_{\mathrm{Fe}}=0.60-0.68, \mathrm{Al}^{\mathrm{VI}}=0.49-0.68\right.$, and $\left.\mathrm{Ti}=0.11-0.15 \mathrm{pfu}\right)$, muscovite (Ms91-94, Pg9-6, Si=3.01-3.21 pfu), plagioclase (Ab60-67, An38-32, and Or0-2), quartz, graphite, and ilmenite. The foliation smoothly wraps around subeuhedral to euhedral crystals of andalusite (up to $5 \mathrm{~mm}$ ) that contain abundant inclusions of graphite, which define a sigmoidal internal schistosity continuous with the matrix foliation S2 (Figure 4f). Anhedral crystals of chemically zoned garnet (up to $2 \mathrm{~mm}$; Prp $4 \rightarrow 7$, Grs $17 \rightarrow 8$, Sps $8 \rightarrow 14$, and $\left.X_{\mathrm{Fe}}=0.95 \rightarrow 0.91\right)$ and plagioclase $(0.5-1 \mathrm{~mm}$, Ab67-75, An33-23, and Or0-2) are wrapped by $S_{2}$ and contain inclusions of graphite, muscovite, biotite, quartz, and ilmenite. The inclusions define an internal schistosity, commonly curved and generally at high angle to and discontinuous with S2. However, graphite inclusion trails in some small plagioclase crystals are continuous with S2.

It is interpreted that garnet and plagioclase crystallized during the development of S1, in equilibrium with biotite, ilmenite, muscovite, and quartz. The rimward increase of the spessartine content in garnet suggests diffusional reequilibration of garnet rims, due to an incomplete resorption. This assemblage is overprinted by the S2 foliation that developed in the stability field of andalusite, plagioclase, biotite, muscovite, quartz, ilmenite, and possibly garnet.

\subsubsection{MS1-P-T Conditions}

A P-T pseudosection has been calculated in the model system MnNCKFMASHTO for the analyzed bulk composition of the sample MS1 (BB06-23B) (Table 1 and Figure 7d) and contoured with compositional isopleths for garnet in order to obtain tighter constraints on the equilibration conditions. Nevertheless, the partial diffusional reequilibration of the garnet chemical composition implies that it should be used with caution and as a rough indication only. Using the range of the spessartine and grossular contents in garnet, it is inferred that garnet crystallized at approximately $5.5 \mathrm{kbar}, 550^{\circ} \mathrm{C}$. This value agrees with the results of the THERMOCALC multiequilibrium thermobarometric calculations (avPT), which give $5.4 \pm 1.4$ kbar, $516 \pm 99^{\circ} \mathrm{C}$ (Table 3 ).

The syn-S2 assemblage is stable in the field g-and-bi-pl-ilm, which occurs around $550^{\circ} \mathrm{C}$ (between 490 and $630^{\circ} \mathrm{C}$ ), and $\mathrm{P}<4$ kbar. The calculated mineral compositions slightly differ from the measured ones, and it was not possible to further constrain the conditions of development of S2 using the calculated isopleths. 


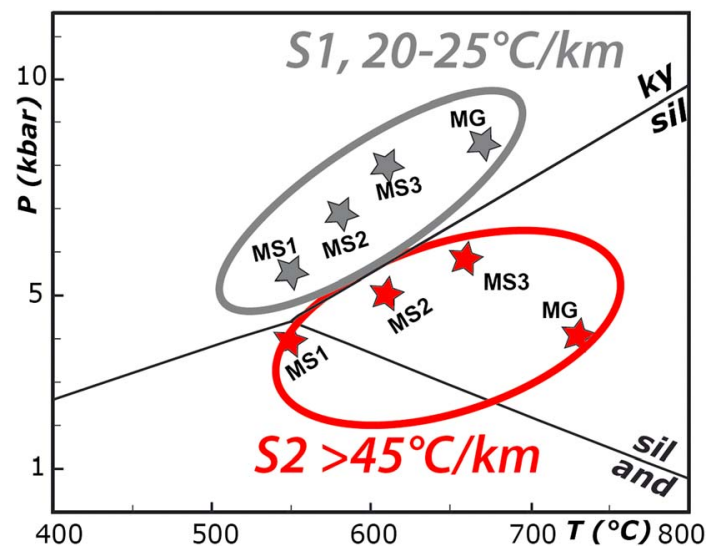

Figure 9. Differences in P-T gradient from our estimates of P-T conditions for S1 and S2 in the Filali unit.

\subsection{S1 and S2 Metamorphic Conditions in the Filali Metapelites}

In summary, the metamorphic rocks of the Filali unit, overlying the Beni Bousera peridotite body and the immediate granulite envelope, are characterized by two main superposed foliations, S1 and S2, each associated with distinct mineral assemblages (Figure 5) and therefore two distinct metamorphic gradients (Figure 9). For both fabrics, going away from the contact with the peridotite, toward the top of the Filali unit, the metamorphic grade decreases. The syn-S1 conditions decrease from $670^{\circ} \mathrm{C}, 8.5 \mathrm{kbar}$ in the migmatitic gneiss to approximately $550^{\circ} \mathrm{C}, 5.5 \mathrm{kbar}$ in the MS1 micaschists and define a metamorphic gradient of Barrovian type (Figure 10). For S2, syndeformational peak temperatures decrease upward from $>730^{\circ} \mathrm{C}$ in the migmatitic gneiss to approximately $550^{\circ} \mathrm{C}$ in the MS1 micaschists. However, associated metamorphic pressures, estimated at about 3-6 kbar, are similar in the entire unit, but significantly lower than those of S1. S2 is therefore associated with a higher-temperature gradient (LP-HT type). This temperature increase during S2 metamorphism is also evident from the thermal structure of the Filali unit reconstructed from Raman spectroscopic analyses of graphitic material [Negro et al., 2006].

The observation of LP-HT assemblages overprinting earlier Barrovian ones is a classic feature and is typically interpreted in terms of monocyclic clockwise P-T paths resulting from crustal thickening and subsequent exhumation (isothermal or accompanied by moderate heating or cooling). However, in the Filali unit, we have shown above textural and petrological evidence against such a simple monocyclic evolution. In what follows we present geochronological data related to $\mathrm{S} 1$ and $\mathrm{S} 2$ fabrics that constrain the ages of these two distinct metamorphic gradients.

\section{Geochronolgy}

The first issue to be addressed when dealing with the tectonic history of the region is the monocyclic versus polycyclic character of the metamorphism. This means, whether the crystallizations associated with $\mathrm{S} 1$ and S2 are stages of the same event or whether each of them belongs to a different orogenic/metamorphic cycle (e.g., Variscan versus Alpine). Based on the available geochronological data, the deformation associated with S2 is commonly ascribed to the Cenozoic period (circa 25-20 Ma) [Blichert-Toft et al., 1999; Platt et al., 2003a; Pearson and Nowell, 2004; Michard et al., 2006]. However, Montel et al. [2000] have shown that monazite in the foliation of the granulites crystallized in Cenozoic times, but those
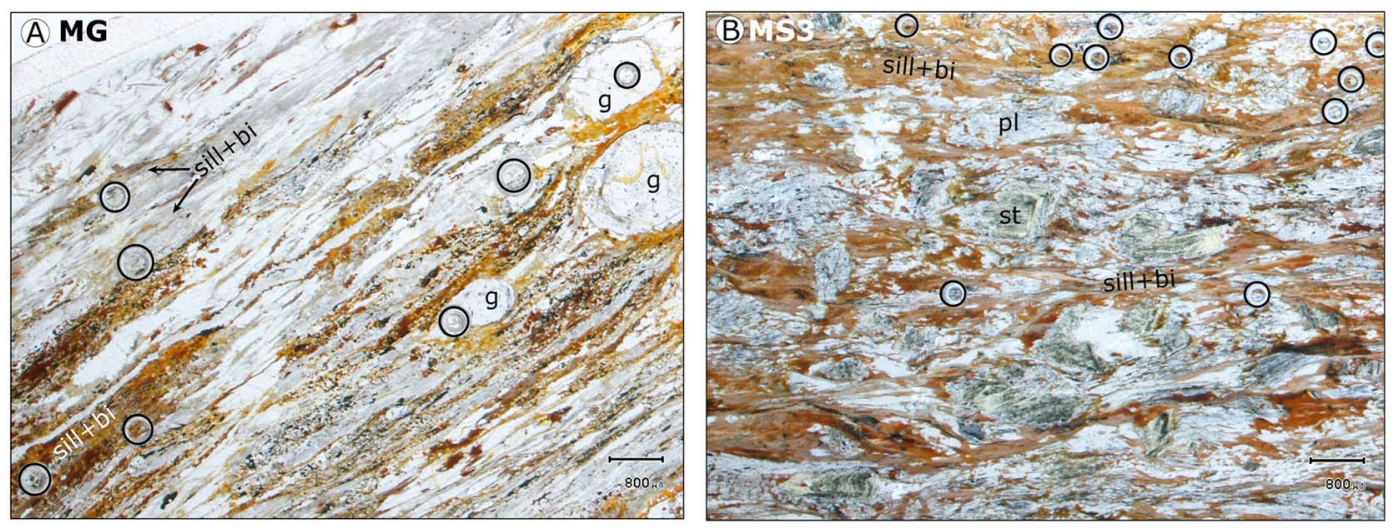

Figure 10. Location of analyzed monazite crystals in the migmatitic gneiss MG (a) and the micaschist MS3 (b). 
included in garnet porphyroclasts yielded late Variscan ages. This demonstrated that the granulites experienced a polycyclic evolution.

The petrological analysis (in particular the two distinct generations of garnet) suggests that the migmatitic gneiss MG recorded also a polycyclic evolution. To test this, an attempt has been made to date monazite grains in different textural positions by in situ LA-ICP-MS dating, directly in context within thin sections, in the migmatitic gneiss and the MS3 micaschists of the Filali unit.

\subsection{Geochronological Procedure}

Monazite grains were imaged using a Jeol JSM 6400 scanning electron microscope at the Centre de Microscopie Electronique à Balayage et microAnaylse (CMEBA) laboratory (Rennes 1 University) in order to identify monazite grains included in garnet, which is difficult to achieve under a petrological microscope as both minerals present similar refractive indices. All of the monazite U-Th-Pb ages were obtained directly "in context" in thin sections by in situ laser ablation inductively coupled plasma mass spectrometry (LA-ICP-MS) dating performed at the at the Laboratoire Magmas et Volcans in Clermont-Ferrand, France. Ablation spot diameters of $7 \mu \mathrm{m}$ with repetition rates of $1 \mathrm{~Hz}$ were used. Data were corrected for $\mathrm{U}-\mathrm{Pb}$ and $\mathrm{Th}-\mathrm{Pb}$ fractionation and for the mass bias by standard bracketing with repeated measurements of the Moacyr monazite standard [Gasquet et al., 2010]. Data reduction was carried out with the GLITTER ${ }^{\circledast}$ software package developed by the Macquarie Research Ltd. [Jackson et al., 2004]. Concordia ages and diagrams were generated using Isoplot/Ex [Ludwig, 2001] and are plotted at the 2 sigma confidence level. All errors given in Table 4 are listed at one sigma, but where data are combined for regression analysis or to calculate weighted means, the final results are provided with $95 \%$ confidence limits. Further information on the instrumentation and the analytical technique is detailed in Hurai et al. [2010].

\subsection{Sample MG}

Two types of monazite were encountered in this sample (Figure 10a). Some monazite grains were found included in garnet porphyroblasts while other grains were disseminated within the matrix minerals. Both types of grains were analyzed and resulting data are listed in Table 4. For some of the analyses, once the background $\left({ }^{204} \mathrm{Hg}\right.$ and $\left.{ }^{204} \mathrm{~Pb}\right)$ signal was removed from the total counts on mass 204, a slight positive value for the ${ }^{204} \mathrm{~Pb}$ was still present. This is very probably indicative of the presence of initial "common" $\mathrm{Pb}$ incorporated into the crystal matrix during crystallization. Twenty-eight spots were analyzed out of 19 different monazite grains. The first striking feature is the large difference in Th content between the two types of monazite. Monazite grains included in garnet present Th content between 1049 and 9758 ppm, while the monazite grains found in the matrix are far richer with Th content between 13420 and $45537 \mathrm{ppm}$ (Table 4). This difference is confirmed when data are plotted in a Tera Wasserburg concordia diagram (Figures 11a and 11b). Monazite grains found in the matrix are all consistent and plot along a discordia yielding an intercept date of $21.3 \pm 0.5 \mathrm{Ma}$ (Mean Squared Weighted Deviation $(\mathrm{MSWD})=1.8$; Figure 11a) if the discordia is anchored to a common ${ }^{207} \mathrm{~Pb} /{ }^{206} \mathrm{~Pb}$ value of 0.837 calculated at $21 \mathrm{Ma}$ using a single-stage Stacey and Kramers [1975] value. This date is consistent with the weighted average mean ${ }^{208} \mathrm{~Pb} /{ }^{232} \mathrm{Th}$ date of $21.95 \pm 0.11 \mathrm{Ma}(\mathrm{MSWD}=0.31 ; \mathrm{N}=21$ ). We therefore conclude that the monazite found in the matrix crystallized at circa $21 \mathrm{Ma}$. One of the monazite grains (m2-Gt, Table 4) was included in the computation of this discordia age although it was found in a garnet porphyroblast. This monazite grain was located at the periphery of the garnet grain (corresponding to the second generation of garnet growth) and consequently might have crystallized during this Alpine event.

The remaining monazite grains are very scattered and plot in a discordant position (Figure 11b). Because of this scattering, which was probably caused by a complex $\mathrm{Pb}$ behavior in the grains (incorporation of common $\mathrm{Pb}$ and/or $\mathrm{Pb}$ loss), it is not possible to compute any meaningful age. It is, however, evident that the absolute age of these monazite grains is significantly older than the grains found in the matrix.

\subsection{Sample MS3}

In this micaschist sample, monazite grains were found only in the matrix (Figure 10b). Here again, the presence of initial common $\mathrm{Pb}$ was evidenced for most of the grains. Thorium contents are also very high with absolute values between 3203 and 44209 ppm. Thirteen measurements out of eleven different monazite grains were performed (Table 4). Plotted in a Tera Wasserburg concordia diagram they plot in a discordant position (Figure 11c). If we anchored the resulting discordia line to a ${ }^{207} \mathrm{~Pb} /{ }^{206} \mathrm{~Pb}$ value of 0.837 


\section{QAGU Tectonics}

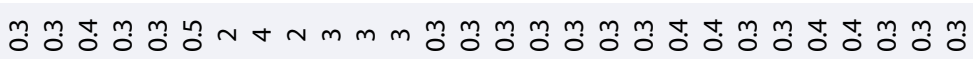

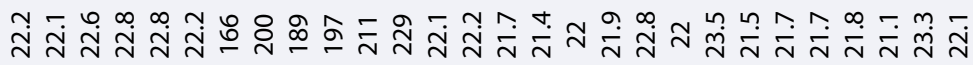

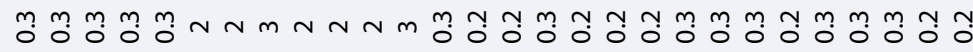

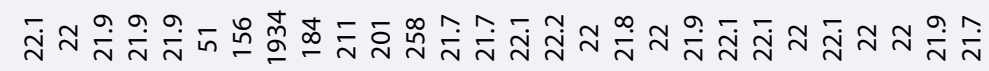

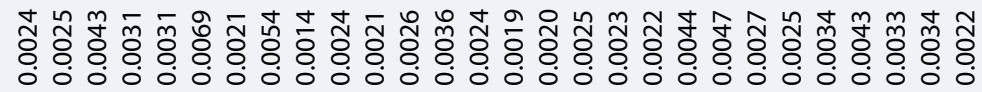

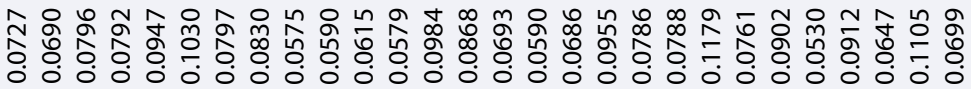

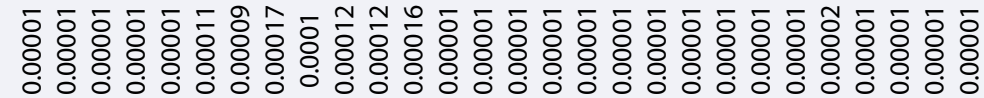

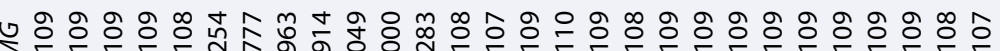

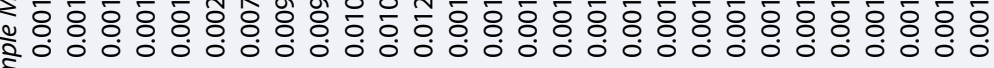
है

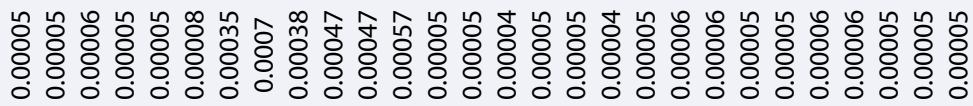

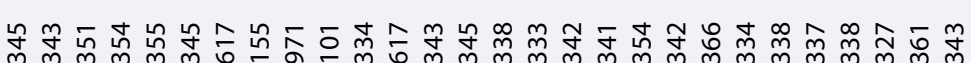

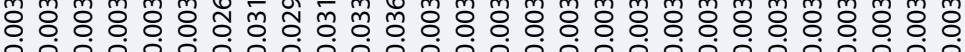

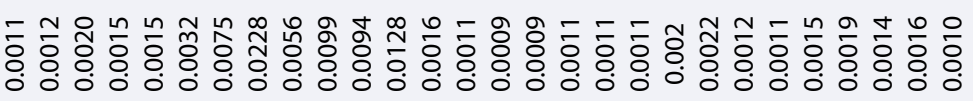

レ

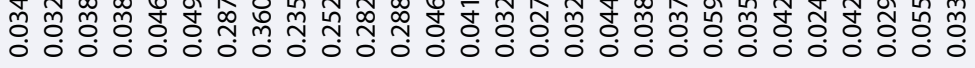

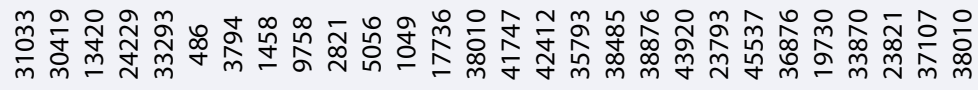

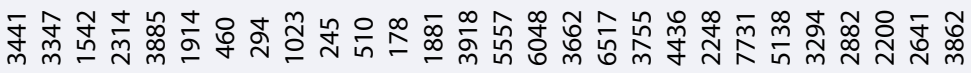

ㅇํำ市

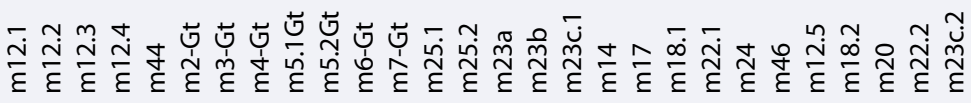

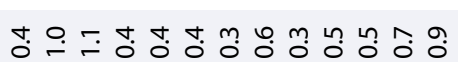

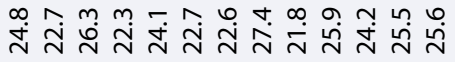

ํㅜㅇ웅옹

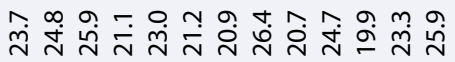

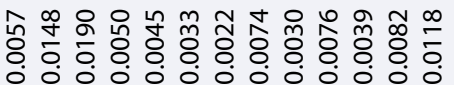

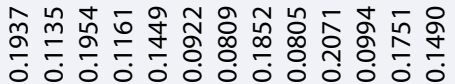

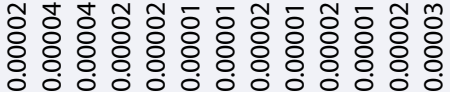

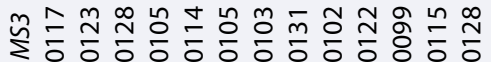

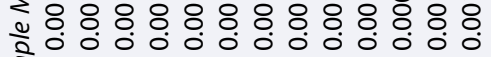
है

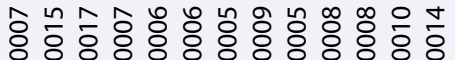

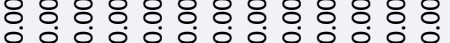

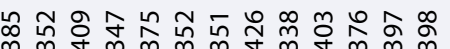
o. 웅ㅇㅇㅇㅇㅇㅇㅇㅇㅇ.

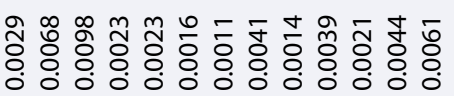

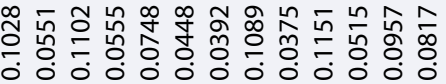

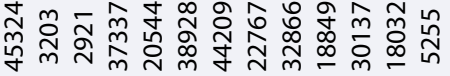

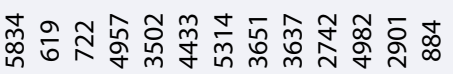

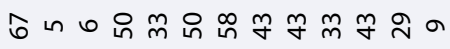

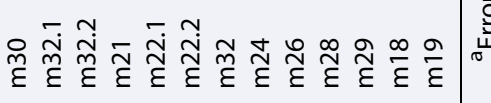



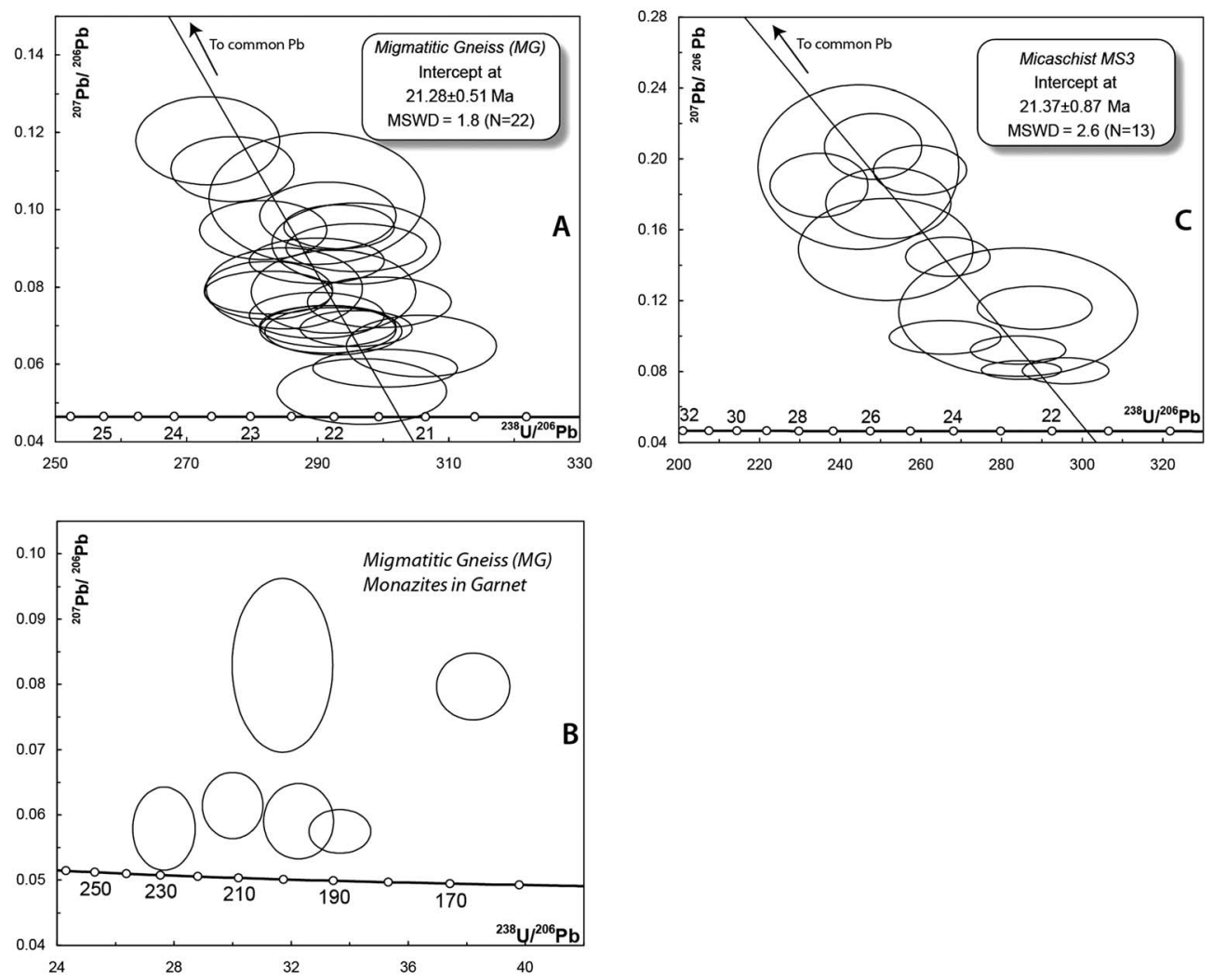

Figure 11. Geochronological data (a and c) from crystals located in the S2 foliation in MG and MS3, respectively, and (b) from monazite included in S1 garnet in MG.

corresponding to the common Pb value calculated at 21 Ma following the Stacey and Kramers [1975] singlestage model, the resulting intercept date is $21.4 \pm 0.9 \mathrm{Ma}$ (MSWD =2.6; Figure 11c). The weighted average ${ }^{208} \mathrm{~Pb} /{ }^{232} \mathrm{Th}$ date is not well constrained in this case with a value of $21.9 \pm 1.1 \mathrm{Ma}(\mathrm{MSWD}=28$ ) because of some scattering encountered in the data set. This date of $21.4 \pm 0.9 \mathrm{Ma}$ is identical within error to the age found for the monazite grains located in the matrix of sample MG. Consequently, we conclude that this age of circa 21 Ma dates the formation of the main foliation S2 in the metamorphic envelope of the Beni Bousera peridotites.

\section{Discussion}

\subsection{Interpretation of Geochronological Data}

As outlined above, the geological significance of the U-Th-Pb behavior of monazite from the metapelite of the Filali unit is paramount in evaluating the various events that have affected this crustal section of the Alboran Domain. This is particularly important since there is still no clear consensus on the age of the Barrovian metamorphic event recognized in basement rocks preserved in the western Mediterranean orogen.

The analyses of metamorphic monazite from the micaschist MS3 and the migmatitic gneiss (MG) from the Filali unit testify to two distinct tectonometamorphic episodes. Metamorphic and geochronological constraints suggest that the first event, associated with S1 fabrics, is older (250-170 Ma). It is therefore likely Variscan, but the data do not allow either confirming or rejecting this hypothesis. The second event, associated with the regional foliation S2, is Alpine (at circa $21 \mathrm{Ma}$ ).

The older age is in good agreement with ages obtained from U-Th-Pb electron microprobe dating of monazite grains enclosed in garnet $(284 \pm 27 \mathrm{Ma})$ from the Beni Bousera granulites [Montel et al., 2000] and confirms the earlier suggested Variscan event in the Lower Sebtides [Michard et al., 1997; Bouybaouène et al., 1998]. The age results presented here are also consistent with U-Pb zircon ages from Alpujarride 
nappe complex in the Betic Cordillera ( $285 \pm 5 \mathrm{Ma}$ and $313 \pm 7 \mathrm{Ma}$ from the lower orthogneisses and the upper schist complex of the Torrox basement section, respectively; Zeck and Whitehouse [2002]; and $330 \pm 9$ and $265 \pm 4 \mathrm{Ma}$ from the granulites and gneisses directly overlying the Ronda peridotite; Ruiz Cruz and Sanz de Galdeano [2014]). Taken together, these data attest to the occurrence of a major Variscan tectonometamorphic event in the Alboran Domain, as also recently discussed by Sánchez-Navas et al., 2014.

The main population of monazite, from the metapelite of the Filali unit (micaschist and migmatitic gneiss), essentially composed of interstitial grains from the main regional foliation $\mathrm{S} 2$, produced U-Th- $\mathrm{Pb}$ ages clustering at circa $21 \mathrm{Ma}$. This age is compatible with the majority of the geochronological data available from the region [see Michard et al., 2006, and references therein]. Lu-Hf and Sm-Nd ages bracketed between circa 25 and $20 \mathrm{Ma}$ are reported from garnet pyroxenite layers of the Beni Bousera peridotites [Blichert-Toft et al., 1999; Pearson and Nowell, 2004]. A comparable sensitive high-resolution ion microprobe (SHRIMP) age of $22.7 \pm 0.3 \mathrm{Ma}$ was obtained on zircon rims from the granulite [Platt et al., 2003a]. Fast cooling rate following peridotites emplacement is implied by a ${ }^{40} \mathrm{Ar} /{ }^{39} \mathrm{Ar}$ biotite age of $22.5 \pm 0.5 \mathrm{Ma}$ from a granulite sample around the Beni Bousera peridotite [Michard et al., 2006]. These 22-25 Ma ages are indistinguishable from those of retrograde monazite from low-T/high-P schists from Beni Mezala, $100 \mathrm{~km}$ north of Beni Bousera that gave ages of about 21 Ma [Janots et al., 2006]. Similarly, in the Betic Cordillera, a Sm-Nd age of 21.5 $\pm 1.8 \mathrm{Ma}$ from garnet-clinopyroxene pairs [Zindler et al., 1983] and a U-Pb zircon age of 19.9 $\pm 1.7 \mathrm{Ma}$ [Sánchez-Rodriguez and Gebauer, 2000] are reported from the garnet pyroxenite layers of the Ronda massif. The final emplacement of the Ronda peridotite was coeval with high $\mathrm{T}$ metamorphism as dated by the U-Pb method on metamorphic rims of zircon from gneisses at between $19.3 \pm 0.3$ and 21.2 $\pm 0.7 \mathrm{Ma}$ [Platt and Whitehouse, 1999] and anatexis of surrounding rocks at around 21-20 Ma [Rossetti et al., 2010].

\subsection{Metamorphic Evolution of the Internal Rif}

The S1 mineral assemblages yield P-T conditions increasing from $550^{\circ} \mathrm{C}, 5.5 \mathrm{kbar}$ in the micaschists to $670^{\circ} \mathrm{C}$, $8.5 \mathrm{kbar}$ in the migmatitic gneiss. These P-T conditions indicate that the Filali unit was buried along a Barrovian metamorphic gradient of the order of $20-26^{\circ} \mathrm{C} / \mathrm{km}$, typical of a collision setting. The HP-HT conditions reported from the granulites both in Rif and in the Betic [ Bouybaouène et al., 1998; Ruiz Cruz and Sanz de Galdeano, 2014] are compatible with such a gradient and reflect the deeper crustal origin of these rocks. The age of circa $250 \mathrm{Ma}$ obtained from monazite inclusions in garnet suggests that this collision is probably attributable to the Variscan orogeny.

The main foliation in the Filali crustal rocks and in the peridotites (S2) developed subsequently, during late Oligocene to early Miocene lithosphere thinning. The results of P-T calculations indicate that equilibration temperatures of peak metamorphic assemblages in the main foliation S2 increase downward in the rock pile from $550^{\circ} \mathrm{C}$ in the micaschists to $>730^{\circ} \mathrm{C}$ in the migmatitic gneiss, for pressures roughly comprised between 3 and $6 \mathrm{kbar}$. This yields a metamorphic field gradient of more than $45^{\circ} \mathrm{C} / \mathrm{km}$. The Filali unit underwent therefore a polyorogenic evolution characterized by an intermediate-to-high-pressure Variscan cycle followed by a HT-LP cycle of Alpine age.

The granulites located between the peridotite and the Filali unit have also recorded a polycyclic evolution. Remnants of an early metamorphic event, probably Variscan, are particularly well preserved in metabasic lenses locally found in the granulites [Michard et al., 1997; Bouybaouène et al., 1998; Montel et al., 2000]. The P-T conditions of this event (S1) are estimated at $16-20 \mathrm{kbar}, 760-820^{\circ} \mathrm{C}$ (Ichendirene HP-granulite) [Bouybaouène et al., 1998]. The aluminous granulites representing the majority of the immediate envelope of the peridotites, are characterized by a mylonitized migmatitic layering that defines the main foliation S2. The P-T conditions of the synkinematic S2 assemblage have been estimated at $9-13 \mathrm{kbar}, 800-850^{\circ} \mathrm{C}$ (Figure 12) [El Maz and Guiraud, 2001] and dated at circa $22 \mathrm{Ma}$ [Platt et al., 2003a]. This foliation wraps large garnets (remnant of S1) that contain metamorphic monazite of Variscan age (circa $284 \pm 27 \mathrm{Ma}$ ) [Montel et al., 2000]. Locally, very fine-grained postkinematic cordierite + spinel symplectites develop at the expense of the aluminum silicates and a cordierite corona locally surrounds large garnet crystals. These assemblages equilibrated probably at approximately $4-5 \mathrm{kbar}, 650-750^{\circ} \mathrm{C}$ (Figure 12) [El Maz and Guiraud, 2001].

Afiri et al. [2011] have shown that the P-T evolution of the Beni Bousera peridotites is characterized by a decompression from approximately $22 \mathrm{kbar}, 1050^{\circ} \mathrm{C}$ to approximately $9-15 \mathrm{kbar}, 800^{\circ} \mathrm{C}$, corresponding to an uplift of at least $30 \mathrm{~km}$ but possibly up to $55 \mathrm{~km}$ (Figure 12). This decompression is contemporaneous 

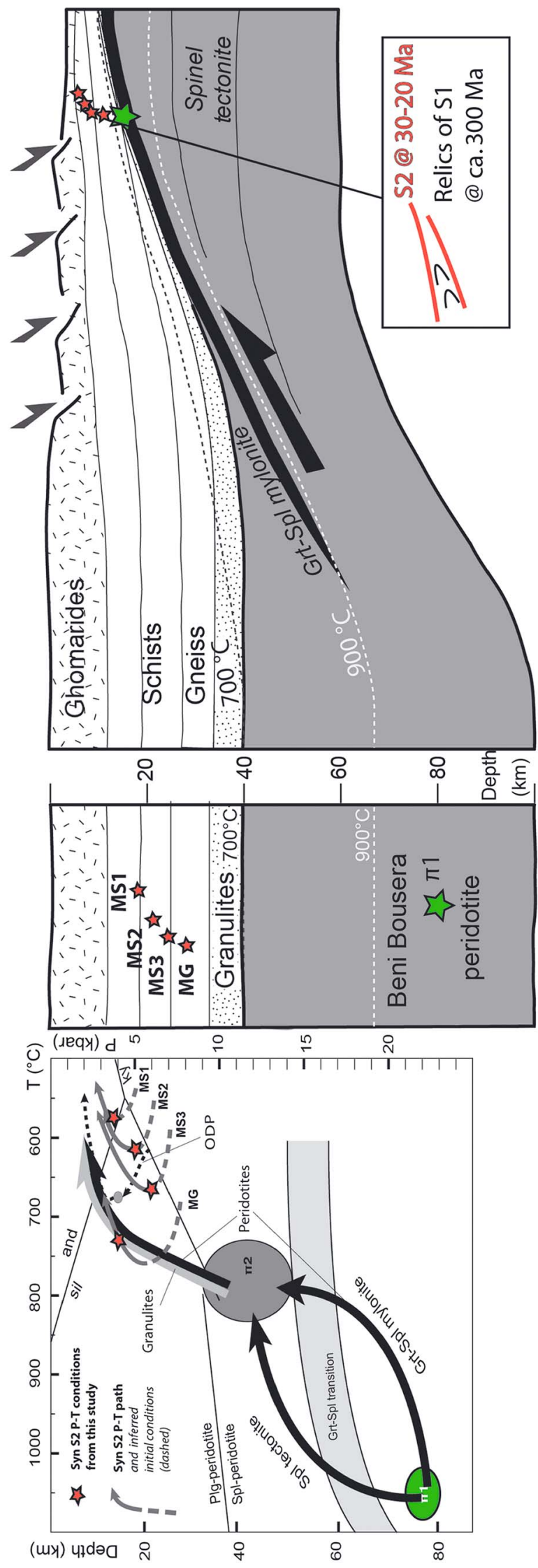

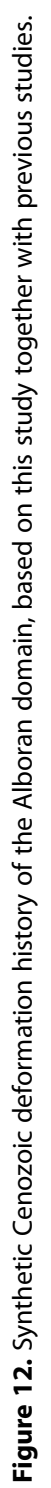


with the development of the main foliation S2 in the rim of the peridotite massif, and is thus here interpreted as being Oligo-Miocene in age. Lu-Hf and Sm-Nd ages between 25 and $20 \mathrm{Ma}$ from garnet pyroxenite layers of the Beni Bousera peridotites support this interpretation [Blichert-Toft et al., 1999; Pearson and Nowell, 2004].

The LP-HT character of the Alpine metamorphism reported here strongly contrasts with the HP-LT subduction-related gradient inferred for the Upper Sebtides (Federico unit) [Chalouan and Michard, 2004]. However, no evidence for a HP-LT metamorphism of Alpine age has been found in the Filali unit, i.e., in the Lower Sebtites. Two hypotheses can explain the absence of Alpine HP-LT metamorphism in the lower Sebtides.

1. The HT character of the Oligocene-lower Miocene metamorphism in the Lower Sebtides may have completely obliterated the former HP-LT metamorphism. This hypothesis is questionable since remnants of a HP-HT Variscan event are found in these rocks, as documented in this paper.

2. The Lower Sebtides were not subjected to Alpine subduction. This hypothesis would imply the existence of a major tectonic contact between the Lower and Upper Sebtides, not documented so far and beyond the scope of the present paper.

The Internal Rif underwent therefore a polyorogenic evolution that comprised a Variscan cycle characterized by an intermediate P/T gradient (including HP-HT granulite-facies metamorphism) followed by a LP-HT event of Alpine age. After the Variscan crustal thickening [Michard et al., 1997; Bouybaouène et al., 1998; Ruiz Cruz and Sanz de Galdeano, 2014], the late Variscan crust (granulite, gneiss, and micaschists) became the basement of the Mesozoic sediments deposited at the Tethyan margin [Chalouan et al., 2008]. This first lithosphere thinning, Mesozoic in age, possibly triggered the Beni Bousera peridotite exhumation from the diamond stability field $(>150 \mathrm{~km})$ to lithosphere mantle depths $(80-90 \mathrm{~km})$ [Sanchez-Rodriguez and Gebauer, 2000]. The later Alpine subduction is only recorded in the Mesozoic sediments of the Upper Sebtides (Federico and Beni Mezala units). The Alpine cycle recorded in the entire Filali unit reflects instead the thinning of the continental lithosphere, characterized by decompression. Based on our P-T estimates for S2 (Figure 8), Figure 12 presents the hypothetical vertical positions of the Beni Bousera peridotites and Filali unit within the continental lithosphere before this thinning event. The peak pressure of S2 in granulite was taken here as a proxy to constrain the Moho depth at around $40 \mathrm{~km}$. The calculation of a stationary geotherm based on the peridotite temperature of $1100^{\circ} \mathrm{C}$ at $80-90 \mathrm{~km}$ depth (Figure 12), results in a Moho temperature of around $700^{\circ} \mathrm{C}$, at $40 \mathrm{~km}$ depth. Assuming such a geotherm together with our P-T estimates of S2, the Filali unit was located at depths comprised between 25 and $10 \mathrm{~km}$, at a middle to deep crustal level. Oligo-Miocene lithosphere thinning lead to the exhumation of deep units, controlled in part by the large shear zone that separates the crustal units from the underlying peridotites. Units that were separated by more than $70 \mathrm{~km}$ depth are consequently juxtaposed within this extremely thinned continental lithosphere (Figure 12). The exhumation of the hot peridotites led to heating of the overlying crustal rocks and the observed LP-HT metamorphism (Figure 12). The resulting heat transfer caused rapid cooling of the mylonitized margin of the peridotite massif and coeval heating of the crustal rocks. This interpretation is consistent with the HT thermal event recorded in all of the crustal rocks [Bouybaouène et al., 1998; El Maz and Guiraud, 2001; Chalouan and Michard, 2004; Michard et al., 2006; Negro et al., 2006; Massonne, 2014], the related magmatism [Rossetti et al., 2010], and the increase in temperature during decompression reported from the Ocean Drilling Project site within the Alboran sea (ODP in Figure 12) [Soto and Platt, 1999]. Note that part of the lower crust, between the granulite and the gneiss, is missing in the present-day lithosphere section (Figure 12), suggesting that thinning was probably concentrated in the lower crust. Numerical models have shown that this feature is necessary to allow very narrow continental rifting and hence lithosphere thinning [Gueydan et al., 2008; Gueydan and Précigout, 2014].

Although our study does not constrain the geodynamic scenario, the strong Oligo-Miocene lithosphere thinning recorded in the Internal Rif seems to be related to westward slab rollback as it has been recently proposed in the western Betics [Garrido et al., 2011; Précigout et al., 2013], in the Rif [Afiri et al., 2011], and in the whole Alboran domain [Duggen et al., 2004].

\section{Conclusions}

Our study shows that the two foliations present in the crustal envelope of the Beni Bousera peridotite bear different mineral assemblages characteristic of different geothermal gradients and hence different tectonic settings; they also formed at different times. 
The main regional foliation S2 is coherent in all the lithologies from the peridotite to the uppermost micaschists. In the crustal rocks it is associated with mineral assemblages yielding $\mathrm{LP}-\mathrm{HT}$ conditions $\left(500^{\circ} \mathrm{C}\right.$ to $>730^{\circ} \mathrm{C}, 3-6 \mathrm{kbar}$ ) achieved at circa $21 \mathrm{Ma}$. Such conditions are compatible with lithospheric stretching/thinning, responsible for and contemporaneous with the exhumation of the hot peridotites that acted as the main heat source.

A former foliation, S1, can be locally found as strongly stretched isoclinal folds embedded in S2 and typically forms inclusion trails in porphyroblasts anterior to and wrapped by S2. S1 is associated with MT-MP mineral assemblages and a gradient of Barrovian type $\left(550^{\circ} \mathrm{C}, 5.5 \mathrm{kbar}\right.$ to $\left.670^{\circ} \mathrm{C}, 8.5 \mathrm{kbar}\right)$, characteristic of continental collision. Dating of S1 monazite yielded significantly older apparent ages ( $\approx 250-170 \mathrm{Ma}$ ).

Consequently, the Internal Rif rocks underwent a polyorogenic evolution characterized by a Barrovian Variscan cycle, most probably related to crustal thickening, followed by an Alpine HT-LP cycle during Oligo-Miocene times, related to extreme thinning of the continental lithosphere, that lead ultimately to the exhumation of subcontinental mantle rocks.

\section{Acknowledgments}

Very constructive comments made by two anonymous reviewers, the Associate Editor, and the Editor helped improving the manuscript. The data for this paper are available by contacting the corresponding author at frederic.gueydan@um2.fr.

\section{References}

Afiri, A., F. Gueydan, P. Pitra, A. Essaifi, and J. Précigout (2011), Oligo-Miocene exhumation of the Beni-Bousera peridotite through a lithosphere-scale extensional shear-zone, Geodin. Acta, 24, 49-60.

Agard, P. J. M., B. Goffè, A. Baronnet, and M. L. Bouybaouène (1999), TEM evidence for high-temperature (300 $\left.{ }^{\circ} \mathrm{C}\right)$ smectite in multistage clay-mineral pseudomorphs in pelitic rocks (Rif, Morocco), Eur. J. Mineral., 11, 655-668.

Argles, T. W., J. P. Platt, and D. J. Waters (1999), Attenuation and excision of a crustal section during extensional exhumation: The Carratraca Massif, Betic Cordillera, southern Spain, J. Geol. Soc. London, 156, 149-162.

Azañon, J. M., and B. Goffé (1997), Ferro- and magnesiocarpholite assemblages as record of high-P, low-T metamorphism in the central Alpujarrides, Betic Cordillera (SE Spain), Eur. J. Mineral., 9, 1035-1051.

Azañón, J. M., V. García-Dueñas, and B. Goffé (1998), Exhumation of high-pressure metapelites and coeval crustal extension in the Alpujarride complex (Betic Cordillera), Tectonophysics, 285, 231-252.

Balanyá, J. C., J. M. Azañon, M. Sánchez-Gomez, and V. Garcia-Dueñas (1993), Pervasive ductile extension, isothermal decompression and thinning of the Jubrique Unit in the Paleogene (Alpujarride Complex, western Betics, Spain), C. R. Acad. Sci., Ser. II, 316, $1595-1601$.

Balanyá, J. C., V. Garcia-Dueñas, J. M. Azañon, and M. Sánchez-Gomez (1997), Alternating contractional and extensional events in the Alpujarride nappes of the Alboran Domain, Tectonics, 16, 226-238, doi:10.1029/96TC03871.

Blichert-Toft, J., F. Albarède, and J. Kornprobst (1999), Lu-Hf isotope systematics of garnet pyroxenites from Beni Bousera, Morocco: Implications for basalt origin, Science, 283, 1303-1306.

Bouybaouène, M. L., B. Goffè, and A. Michard (1995), High pressure, low-temperature metamorphism in the Sebtides nappes, northern Rif, Morocco, Geogaceta, 17, 117-119.

Bouybaouène, M. L., B. Goffé, and A. Michard (1998), High-pressure granulites on top of the Beni Bousera peridotites, Rif belt, Morocco: A record of an ancient thickened crust in the Alboran domain, Bull. Soc. Geol. Fr., 169, 153-162.

Chalouan, A., and A. Michard (2004), The Alpine Rif belt (Morocco): A case of mountain building in a subduction-subduction-transform fault triple junction, Pure Appl. Geophys., 161, 489-519.

Chalouan, A., A. Michard, H. Feinberg, R. O. Montigny, and O. Saddiqi (2001), The Rif mountain building (Morocco): A new tectonic scenario, Bull. Soc. Geol. Fr., 172, 603-616.

Chalouan, A., A. Michard, K. El Kadiri, F. Negro, D. Frizon de Lamotte, J. I. Soto, and O. Saddiqi (2008), The Rif belt, in The Geology of Morocco, edited by A. Michard et al., pp. 203-302, Springer, Berlin.

Coggon, R., and T. J. B. Holland (2002), Mixing properties of phengitic micas and revised garnet-phengite thermobarometers, J. Metamorph. Geol., 20, 683-696.

Davies, G. R., P. H. Nixon, D. G. Pearson, and M. Obata (1993), Tectonic implications of graphitized diamonds from the Ronda peridotite massif, southern Spain, Geology, 21, 471-474.

Dikey, J. S., M. T. Lundeen, and M. Obata (1979), Geologic Map of the Ultramafic Complex, Southern Spain, Geol. Soc. of Am. Map and Chart Ser., vol. MC-29, pp. 1-4, Geol. Soc. of Am., Boulder, Colo.

Doblas, M., and R. Oyarzun (1989), Neogene extensional collapse in the Western Mediterranean (Betic-Rif alpine orogenic belt): Implications for the genesis of the Gibraltar arc and magmatic activity, Geology, 17(5), 430-433.

Duggen, S., K. Hoernle, P. V. D. Bogaard, and C. Harris (2004), Magmatic evolution of the Alboran region: The role of subduction in forming the western Mediterranean and causing the Messinian Salinity Crisis, Earth Planet. Sci. Lett., 218, 91-108.

El Maz, A., and M. Guiraud (2001), Paragenèse à faible variance dans les mètapèlites de la sèrie de Filali (Rif interne marocain): Description, interpretation et consèquences gèodynamiques, Bull. Soc. Geol. Fr., 172, 469-485.

Esteban, J. J., J. Cuevas, J. M. TubíA, S. Sergeev, and A. Larionov (2011), A revised Aquitanian age for the emplacement of the Ronda peridotites (Betic Cordilleras, southern Spain), Geol. Mag., 148, 183-187.

Frets, E. C., A. Tommasi, C. J. Garrido, A. Vauchez, D. Mainprice, K. Targuisti, and I. Amri (2014), The Beni-Bousera peridotite (Rif belt, Morocco): An oblique-slip low-angle shear zone thinning the subcontinental mantle lithosphere, J. Petrol., 55(2), 283-313.

Garrido, C. J., F. Gueydan, G. Booth-Rea, J. Precigout, K. Hidas, J. A. Padrón-Navarta, and C. Marchesi (2011), Garnet Iherzolite and garnet-spinel mylonite in the Ronda peridotite: Vestiges of Oligocene backarc mantle lithospheric extension in the western Mediterranean, Geology, 39, 927-930.

Gasquet, D., J. M. Bertrand, J. L. Paquette, J. Lehmann, G. Ratzov, R. De Ascencao Guedes, M. Tiepolo, A. M. Boullier, S. Scaillet, and S. Nomade (2010), Miocene to Messinian deformation and hydrothermalism in the Lauzière Massif (French Western Alps): New U-Th-Pb and Argon ages, Bull. Soc. Geol. France, 181, 227-241.

Goffè, B., J. M. Azanon, M. L. Bouybaouène, and M. Jullien (1996), Metamorphic cookeite in Alpine metapelites from Rif, northern Morocco, and the Betic Chain, southern Spain, Eur. J. Mineral., 8, 335-348. 
Gueydan, F., and J. Précigout (2014), Modes of continental rifting as a function of ductile strain localization in the lithospheric mantle, Tectonophysics, 612-613, 18-25.

Gueydan, F., C. Morency, and J. P. Brun (2008), Continental rifting as a function of lithosphere mantle strength, Tectonophysics, 460, 83-93.

Hidas, K., G. Booth-Rea, C. J. Garrido, J. M. Martínez-Martínez, J. A. Padrón-Navarta, Z. Konc, F. Giaconia, E. Frets, and C. Marchesi (2013), Backarc basin inversion and subcontinental mantle emplacement in the crust: Kilometre-scale folding and shearing at the base of the proto-Alborán lithospheric mantle (Betic Cordillera, southern Spain), J. Geol. Soc., 170(1), 47-55.

Holland, T., and R. Powell (2003), Activity-composition relations for phases in petrological calculations: An asymmetric multicomponent formulation, Contrib. Mineral. Petrol., 145, 492-501.

Holland, T. J. B., and R. Powell (1998), An internally consistent thermodynamic data set for phases of petrological interest, J. Metamorph. Geol., 16, 309-343.

Hurai, V., J.-L. Paquette, M. Huraiová, and P. Konečný (2010), U-Th-Pb geochronology of zircon and monazite from syenite and pincinite xenoliths in Pliocene alkali basalts of the intra-Carpathian back-arc basin, J. Volcanol. Geotherm. Res., 198, 275-287, doi:10.1016/ j.jvolgeores.2010.09.012.

Jackson, S. E., N. J. Pearson, W. L. Griffin, and E. A. Belousova (2004), The application of laser ablation-inductively coupled plasma-mass spectrometry to in situ U-Pb zircon geochronology, Chem. Geol., 211, 47-69, doi:10.1016/j.chemgeo.2004.06.017.

Janots, E., F. Negro, F. Brunet, B. Goffè, M. Engi, and M. L. Bouybaouene (2006), Evolution of the REE mineralogy in HP-LT metapelites of the Sebtides complex, Rif, Morocco: Monazite stability and geochronology, Lithos, 87, 214-234.

Kornprobst, J. (1974), Contribution a l'ètude pètrographique et structurale de la zone interne du Rif (Maroc septentrional); Petrography and structure of the Rif inner area, northern Morocco, Notes Mèm. Serv. Gèol. Rabat, 251, 256.

Le Bayon, B., P. Pitra, M. Ballèvre, and M. Bohn (2006), Reconstructing P-T paths during continental collision using multi-stage garnet (Gran Paradiso nappe, Western Alps), J. Metamorph. Geol., 24, 477-496.

Lonergan, L., and N. White (1997), Origin of the Betic-Rif mountain belt, Tectonics, 16, 504-522, doi:10.1029/96TC03937.

Ludwig, K. R. (2001), User's Manual for Isoplot/Ex Version 2.49, A Geochronological Toolkit for Microsoft Excel, Spec. Publ. 1a, Berkeley Geochronological Center, Berkeley.

Massonne, H. J. (2014), Wealth of P-T-t information in medium-high grade metapelites: Example from the Jubrique Unit of the Betic Cordillera, S Spain, Lithos, 208-209, 137-157.

Mazzoli, S., and A. Martín-Algarra (2011), Deformation partitioning during transpressional emplacement of a 'mantle extrusion wedge': The Ronda Peridotites, Western Betic Cordillera, Spain, Q. J. Geol. Soc. London, 168, 373-382.

Michard, A., A. Chalouan, R. Montigny, and M. Ouazzani-Touhami (1983), Les nappes cristallophylliennes du Rif (Sebtides, Maroc), temoins d'un edifice alpin de type pennique incluant le manteau superieur, C. R. Acad. Sci., Ser.ll, 296, 1337-1340.

Michard, A., B. Goffé, A. Chalouan, and O. Saddiqi (1991), Les corrèlations entre les chaînes Bètico-Rifaines et les Alpes et leurs consèquences, Bull. Soc. Geol. Fr., 162, 1151-1160.

Michard, A., B. Goffé, M. L. Bouybaouène, and O. Saddiqi (1997), Late Hercynian Mesozoic thinning in the Alboran domain: Metamorphic data from the northern Rif, Morocco, Terra Nova, 9, 171-174.

Michard, A., A. Chalouan, H. Feinberg, B. Goffé, and R. Montigny (2002), How does the Alpine belt end between Spain and Morocco?, Bull. Soc Geol. Fr., 173, 3-15.

Michard, A., F. Negro, O. Saddiqi, M. L. Bouybaouene, A. Chalouan, R. Montigny, and B. Goffè (2006), Pressure-temperature-time constraints on the Maghrebide mountain building: Evidence from the Rif-Betic transect (Morocco, Spain), Algerian correlations, and geodynamic implications, C. R. Acad. Sci., Ser., 338, 92-114.

Montel, J. M., J. Kornprobst, and D. Vielzeuf (2000), Preservation of old U-Th-Pb ages in shielded monazite: Example from the Beni Bousera Hercynian kinzigites (Morocco), J. Metamorph. Geol., 18, 335-342.

Negro, F., O. Beyssac, B. Goffé, O. Saddiqi, and L. Bouybaouène (2006), Thermal structure of the Alboran Domain in the Rif (northern Morocco) and the Western Betics (southern Spain). Constraints from Raman spectroscopy of carbonaceous material, J. Metamorph. Geol., 24, 309-327.

Obata, M. (1980), The Ronda peridotite: Garnet-, spinel-, and plagioclase-lherzolite facies and the P-T trajectories of a high-temperature mantle intrusion, J. Petrol., 21, 533-572.

Pearson, D. G., and G. M. Nowell (2004), Re-Os and Lu-Hf isotope constraints on the origin and age of pyroxenites from the Beni Bousera peridotite Massif: Implications for mixed peridotite-pyroxenite mantle sources, J. Petrol., 45, 439-455.

Pearson, D. G., G. R. Davies, P. H. Nixon, and H. J. Milledge (1989), Graphitized diamonds from a peridotite massif in Morocco and implications for anomalous diamond occurrences, Nature, 335, 60-66.

Platt, J. P., and M. J. Whitehouse (1999), Early Miocene high-temperature metamorphism and rapid exhumation in the Betic Cordillera (Spain): Evidence from U-Pb zircon ages, Earth Planet. Sci. Lett., 171, 591-605.

Platt, J. P., M. J. Whitehouse, S. P. Kelley, A. Carter, and L. Hollick (2003a), Simultaneous extensional exhumation across the Alboran Basin: Implications for the causes of late orogenic extension, Geology, 31, 251-254.

Platt, J. P., T. W. Argles, A. Carter, S. P. Kelley, M. J. Whitehouse, and L. Lonergan (2003b), Exhumation of the Ronda peridotite and its crustal envelope: Constraints from thermal modelling of a P-T-time array, J. Geol. Soc., 160, 655-676.

Platt, J. P., W. M. Behr, K. Johanesen, and J. R. Williams (2013), The Betic-Rif arc and its orogenic hinterland: A review, Annu. Rev. Earth Planet. Sci., 41, 313-357.

Powell, R., and T. J. B. Holland (1985), An internally consistent dataset with uncertainties and correlations: 1 Methods and a worked example, J. Metamorph. Geol., 3, 327-342.

Powell, R., and T. J. B. Holland (1988), An internally consistent dataset with uncertainties and correlations: 3. Applications to geobarometry, worked examples and a computer program, J. Metamorph. Geol., 6, 173-204.

Powell, R., and T. J. B. Holland (2002), Course Notes for "THERMOCALC Workshop 2002: Calculating Metamorphic Phase Equilibria" [CD-ROM], Barcelona, Spain. [Available at http://www.esc.cam.ac.uk/research/research-groups/research-projects/tim-hollands-software-pages/ax.]

Précigout, J., F. Gueydan, D. Gapais, C. J. Garrido, and A. Essaifi (2007), Strain localisation in the subcontinental mantle-A ductile alternative to the brittle mantle, Tectonophysics, 445, 318-336.

Précigout, J., F. Gueydan, C. J. Garrido, N. Cogné, and G. Booth-Rea (2013), Deformation and exhumation of the Ronda peridotite (Spain), Tectonics, 32, 1011-1025, doi:10.1002/tect.20062.

Reuber, I., A. Michard, A. Chalouan, T. Juteau, and B. Jermoumi (1982), Structure and emplacement of the Alpine-type peridotites from Beni Bousera, Rif, Morocco: A polyphase tectonic interpretation, Tectonophysics, 82, 231-251.

Rossetti, F., T. Theye, F. Lucci, M. L. Bouybaouène, A. Dini, A. Gerdes, D. Phillips, and D. Cozzupoli (2010), Timing and modes of granite magmatism in the core of the Alboran Domain (rif chain, northern Morocco): Implications for the Alpine evolution of the western Mediterranean, Tectonics, 29, TC2017, doi:10.1029/2009TC002487. 
Ruiz Cruz, M. D., and C. Sanz de Galdeano (2014), Garnet variety and zircon ages in UHP meta-sedimentary rocks from the Jubrique zone (Alpujárride Complex, Betic Cordillera, Spain): Evidence for a pre-Alpine emplacement of the Ronda peridotite, Int. Geol. Rev., 56, 845-868. Saddiqi, O. (1995), Exhumation des roches profondes, pèridotites et roches mètamorphiques HP-BT dans deux transects de la chaîne alpine, Arc de Gibraltar et Montagnes d'Oman, PhD thesis, 245 pp., Univ. Hassan II, Casablanca, Morocco.

Saddiqi, O., I. Reuber, and A. Michard (1988), Sur la tectonique de denudation du manteau infracontinental dans les Beni Bousera, Rif septentrional, Maroc, C. R. Acad. Sci., Ser. II, 307, 657-662.

Sánchez-Gómez, M., J. C. Balanyá, V. García-Dueñas, and J. M. Azañón (2002), Intracrustal tectonic evolution of large lithosphere mantle slabs in the western end of the Mediterranean orogen (Gibraltar arc), J. Virtual Explorer, 8, 23-34.

Sánchez-Navas, A., A. García-Casco, and A. Martín-Algarra (2014), Pre-Alpine discordant granitic dikes in the metamorphic core of the Betic Cordillera: Tectonic implications, Terra Nova, 26, 477-486.

Sánchez-Rodriguez, L., and D. Gebauer (2000), Mesozoic formation of pyroxenites and gabbros in the Ronda area (southern Spain), followed by early Miocene subduction metamorphism and emplacement into the middle crust: $\mathrm{U}-\mathrm{Pb}$ sensitive high-resolution ion microprobe dating of zircon, Tectonophysics, 316, 19-44.

Soto, J. I., and J. P. Platt (1999), Petrological and structural evolution of high-grade metamorphic rocks from the floor of the Alboran Sea basin, western Mediterranean, J. Petrol., 40, 21-60.

Stacey, J. S., and J. D. Kramers (1975), Approximation of terrestrial lead isotope evolution by a two-stage model, Earth Planet. Sci. Lett., 26, 207-221, doi:10.1016/0012-821x(75)90088-6.

Tornè, M., E. Banda, V. Garcia-Duenas, and J. C. Balanya (1992), Mantle-lithosphere bodies in the Alboran crustal domain (Ronda peridotites, Betic-Rif orogenic belt), Earth Planet. Sci. Lett., 110, 163-171.

Tubía, J., J. Cuevas, J. Esteban, and J. G. Ibarguchi (2009), Remnants of a Mesozoic rift in a subducted terrane of the Alpujarride complex (Betic Cordilleras, southern Spain), J. Geol., 117(1), 71-87.

Tubía, J., J. Cuevas, and J. Esteban (2013), Localization of deformation and kinematic shift during the hot emplacement of the Ronda Peridotites (Betic Cordilleras, southern Spain), J. Struct. Geol., 50, 148-160.

Van der Wal, D., and R. L. M. Vissers (1993), Uplift and emplacement of upper mantle rocks in the western Mediterranean, Geology, 21, 1119-1122.

Vergés, J., and M. Fernàndez (2012), Tethys-Atlantic interaction along the lberia-Africa plate boundary: The Betic-Rif orogenic system, Tectonophysics, 579, 144-172.

White, R. W., R. Powell, T. J. B. Holland, and B. A. Worley (2000), The effect of TiO2 and Fe2O3 on metapelitic assemblages at greenschist and amphibolite facies conditions: Mineral equilibria calculations in the system K2O-FeO-MgO-Al2O3-SiO2-H2O-TiO2-Fe2O3, J. Metamorph. Geol., 18, 497-511.

White, R. W., R. Powell, and T. J. B. Holland (2007), Progress relating to calculation of partial melting equilibria for metapelites, J. Metamorph Geol., 25, 511-527.

Zeck, H. P., and M. J. Whitehouse (2002), Repeated age resetting in zircons from Hercynian-Alpine polymetamorphic schists (Betic-Rif tectonic belt, S. Spain)—a U-Th-Pb ion microprobe study, Chem. Geol., 182, 275-292.

Zindler, A., H. Staudigel, S. R. Hart, R. Endres, and S. Goldstein (1983), Nd and Sr isotopic study of a mafic layer from Ronda ultramafic complex, Nature, 304, 226-23. 